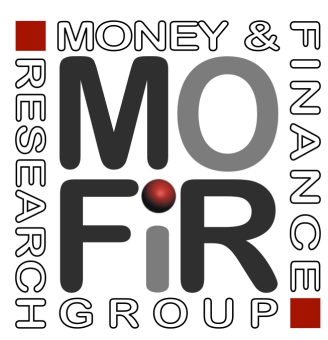

\title{
CAPITAL INFLOWS, EQUITY ISSUANCE ACTIVITY, AND CORPORATE INVESTMENT
}

Charles W. Calomiris Mauricio Larrain

Sergio L. Schmukler

Working paper no. 156 


\title{
Capital Inflows, Equity Issuance Activity, and Corporate Investment
}

\author{
Charles W. Calomiris
}

\author{
Mauricio Larrain
}

Sergio L. Schmukler*

July 12, 2019

\begin{abstract}
This paper uses issuance-level data to study how equity capital inflows that enter emerging market economies affect equity issuance and corporate investment. It shows that foreign inflows are strongly correlated with country-level issuance. The relation especially reflects the behavior of large firms. To identify supply-side shocks, capital inflows into each country are instrumented with exogenous changes in other countries' attractiveness to foreign investors. Shifts in the supply of foreign capital are important drivers of increased equity inflows. Instrumented contemporaneous and lagged capital inflows lead large firms to raise new equity, which they use to fund investment.
\end{abstract}

JEL Classification Codes: F23, F32, F65, G11, G15, G31

Keywords: capital flows, corporate financing, emerging markets, domestic investors, foreign investors, use of funds

\footnotetext{
* Calomiris: Columbia Business School, Hoover Institution, and NBER, email: cc374@columbia.edu; Larrain: Universidad Catolica de Chile School of Management and Financial Market Commission of Chile, email: mauricio.larrain@uc.cl; Schmukler: World Bank Research Department, email: sschmukler@worldbank.org. We thank Laura Alfaro, Gustavo Araujo (discussant), Murillo Campello (editor), Nathan Converse (discussant), Erik Gilje (discussant), Aart Kraay, Jeanne Lafortune, Atif Mian, Gabriel Natividad, Amit Seru, Luis Serven, Jose Tessada, Shang-Jin Wei, Ilknur Zer (discussant), an anonymous referee, and participants at presentations held at the ASSA Annual Meetings, Central Bank of Brazil's Conference on Financial Stability and Banking, Finance UC Conference, Fordham University, Hebrew University, HEC Paris, IMF, Kansas City Fed, LACEA-LAMES Annual Meetings, Southern Economic Association Annual Meetings, Telfer Annual Conference on Accounting and Finance, University of Chile, University of Michigan, University of Santiago Chile, and Vienna Graduate School of Finance for useful comments. We are grateful to Soha Ismail for superb research assistance, to Facundo Abraham, Juan Cortina, Marta Guasch Rusiñol, and Ruth Llovet for their valuable help at different stages of the project, and to Tatiana Didier and Tomas Williams for facilitating access to data. Larrain acknowledges funding from Proyecto Fondecyt Iniciación \#11160879. We received financial support from the World Bank Chile Research and Development Center, Knowledge for Change Program (KCP), and Strategic Research Program (SRP). The views expressed here do not necessarily represent those of the World Bank.
} 


\section{Introduction}

Capital inflows are prevalent in emerging market countries. In 2016, foreign investors invested around 64 billion U.S. dollars into emerging countries in the form of portfolio equity, i.e., foreign investors' purchases of stocks of publicly traded emerging market firms. Despite this large magnitude, one can question whether capital inflows are economically important in spurring development in emerging economies. It is conceivable that large flows of equity associated with significant cross-border diversification of investors' equity holdings might not translate into large effects on firms raising capital in equity markets.

The volatility of capital inflows, including sudden capital inflow reversals ("sudden stops"), has also generated significant debate because of its effects on macroeconomic instability. With encouragement from the International Monetary Fund (IMF), many countries have moved to curb some forms of capital inflows (especially short-term, dollar-denominated debts) through regulatory policies (IMF, 2010; Blanchard, 2019). The risk is that short-term debt can be withdrawn suddenly. Moreover, because some of that debt is denominated in U.S. dollars, its value in local currency terms can substantially increase as the result of a devaluation when capital inflows retrench. In contrast, equity is not a debt obligation, much less a dollardenominated one, and it has no maturity. Thus, from the standpoint of financial stability, equity inflows are a particularly desirable form of access to international capital markets.

But how important are foreign equity inflows as a source of capital for emerging market firms? Which firms have access to use these markets as a source of fundraising, and under which market conditions? To the extent that access to equity markets provides a major source of funding for a broad base of firms, opening equity markets to foreign investors might provide an important source of funds for growth with little of the destabilizing influence of short-term debt. 
In this paper, we address these central questions by examining whether capital inflows have benefited firms in recipient emerging market countries by encouraging firms to issue new equity to fund investment and growth. We take a close look at which types of firms (according to size) respond to inflows by issuing new equity. Most of the evidence that has been assembled to address that question has been indirect, based on aggregate relations rather than firm-level behavior (Kose et al., 2009). Those aggregate findings depend upon potentially controversial identification (e.g., fully controlling for other macroeconomic changes that may coincide with capital inflows), and do not identify the mechanisms through which inflows can affect firm performance and growth.

We demonstrate the importance of equity inflows for real economic activity by providing micro evidence at the firm level on the channels of transmission through which equity inflows can induce corporate investment. We study how equity capital inflows affect the economies that receive them by analyzing their connection to equity financing (through firm-level equity issuance) and to real economic activity (through changes in corporate investment). We investigate whether publicly traded firms in emerging countries issue more equity when their countries experience increases in foreign equity purchases and what firms do with the equity capital they raise. In particular, we ask whether the firms that raise new equity use those funds to finance corporate investment. ${ }^{1}$ We also analyze whether firms of different size differ in the degree to which their issuance of new equity responds to increased funding by foreign equity investors.

\footnotetext{
${ }^{1}$ We focus on equity financing, which is especially important for expanding the growth opportunities of firms. Most of the literature on financial globalization and financial liberalization has focused on equity markets. Moreover, a larger array of firms from emerging economies issue equity than public debt, which allows us to consider heterogeneous effects across a wider range of firms. Furthermore, well-known indexes for equity markets exist, which guide foreign investors to invest in those economies. In addition, financial statements data on firms across countries are mostly available for those firms listed in equity markets. These data are important to understand the real effects of capital inflows.
} 
Ours is the first study, of which we are aware, that examines the links between capital inflows and investment using issuance-level data. To do so, we assemble a large granular dataset containing information on 20,306 seasoned equity issuances (SEOs) and financial statements for 12,723 firms in 25 emerging market countries, in addition to capital inflows during the 26-year period 1991-2016. The total number of firm-year observations is 330,798.

Our study not only establishes the existence of a link between foreign investors' purchases of equity and firms' issuances of new equity, it also shows that this correlation largely reflects variation in the supply of funding rather than variation in firms' investment opportunities. Figure 1 presents the evolution of the aggregate amount of equity investing by foreign investors into our sample countries alongside the total value of seasoned equity raised by firms in those countries. The figure shows that periods of large capital inflows coincide with periods of active equity issuance activity.

It is important to recognize that there is no mechanical connection between foreign purchases of stock and firm stock issuance. Foreign investors could purchase existing shares of stock from stockholders without causing firms to issue new shares. But if increases in foreign purchases of stock are associated with increased supply of funding by foreign investors that produce reductions in the required rate of return on equity faced by firms, then one would expect increases in capital inflows to be associated with new equity issuance. Figure 1 shows, therefore, that inflows are associated with more than a simple transfer of equity ownership from domestic to foreign investors.

We also seek to identify the causal link between changes in international investors' supply of funds in the equity market and emerging market firms' issuances of equity. We base our identification strategy on the use of firm-level data together with a novel instrument for equity inflows, which allow us to shed light on the importance of supply-side and demand- 
side influences. We first estimate the country-level relation between capital inflows and equity issuance. We regress each country's equity issuances on equity inflows, taking into account country and year fixed effects. We find a strong association between the two. For every million U.S. dollars foreign investors purchase of emerging market equity, the value of seasoned issuance proceeds increases by 160,000 U.S. dollars.

We then move to the micro-level analysis to better understand the mechanisms that drive these aggregate issuance patterns. We first regress firm-level issuance proceeds on equity capital inflows, controlling for firm and year fixed effects. We find only a weakly significant correlation between capital inflows and the value of issuance proceeds for the typical emerging market firm.

When we divide firms into groups according to size, we find a large and statistically significant effect of equity inflows on the issuances of large firms. We define large firms as those in the top decile of size of market value of equity within a country in the previous year. This result is consistent with the well-known fact that international investors are particularly interested in investing in the shares of large, well-established emerging market firms. The higher responsiveness of large firms' issuances to equity capital inflows remains even after controlling for country-year fixed effects, which allows us to control for all time-varying country shocks. Moreover, we find that the relation between equity capital inflows and equity issuance is monotonically increasing in firm size.

Given that an increase in issuance activity could reflect either an increase in foreign equity supply by investors or greater domestic equity demand by firms, we develop an instrumental variable (IV) approach that identifies supply-side influences. We identify supply shocks to equity inflows by measuring shifts in foreign investor interest unrelated to changes in domestic firms' prospects. In particular, we instrument equity inflows using the 
attractiveness of other countries' equity markets to foreign investors, which we argue is plausibly exogenous to demand-side shocks to the subject country. The idea is that, for a given amount of total capital inflows to emerging markets as a whole, positive shocks to other countries' attractiveness to foreign investors constitute negative shocks to the subject country's supply of funds. ${ }^{2}$

We provide regression results using two alternative measures of our instrument, both of which are strongly correlated with equity capital inflows. In particular, we employ the orthogonalized sum of other countries' total equity value and the orthogonalized amount of other countries' equity issuances. Our instrumenting procedure orthogonalizes the sum of other countries' equity values (the sum of issuances) with respect to the market value (the issuances volume) in the subject country, which removes common shocks. These two instruments depend exclusively on foreign shocks and are therefore exogenous to demand shocks of the subject country. In addition, to deal with the possibility that equity inflows to emerging markets can be correlated across countries, our specification includes year fixed effects, which control for common shocks across them. We find that using either of the two measures of our instrument, instrumented inflows, contemporaneous and lagged, lead large firms to raise significantly more equity.

Our data on capital inflows are measured annually and the precise timing lag between the stimulus of instrumented capital inflows and the response of issuances is not known a

\footnotetext{
2 As we discuss in Section III, other facts about the association between equity inflows and issuances are suggestive of supply-driven causality. The fact that the response of issuances to equity inflows is greater among large firms suggests a supply-side channel. If inflows were simply responding to improved economic conditions in the country, one might expect all firms, not just large ones, to issue more equity at times of large capital inflows (our country-year fixed effects control for all shocks that affect all firms equally in a country). The finding that inflows tend to prompt issuances particularly by large firms suggests that those firms may be especially attractive to foreign equity investors. However, one cannot rule out that demand-side shocks are heterogeneous across firms. The fact that lagged inflows predict equity issuances is also suggestive of supply-driven causality, but here too, it is conceivable that serially correlated demand shocks could account for the correlation between lagged equity inflows and equity issuances.
} 
priori. Therefore, when modeling the timing of the connection between instrumented capital inflows and equity issuances, we consider two alternative dynamic formulations. In one formulation, we regress issuances on contemporaneous inflows (where it is possible that issuances could occur at the same time as the capital inflows, or slightly before or after the inflows but within the same year). In the second formulation, we regress issuances on lagged inflows. Our results are similar under either of the two formulations. ${ }^{3}$ Moreover, the fact that we find a significant relation between lagged inflows and subsequent issuances shows that the connection between inflows and issuances is not driven by a mechanical link between contemporaneous issuances that attract foreign purchases.

In our final empirical analysis, we study the real effects of equity capital inflows. First, using the same instruments that we employ to gauge the effect of funding supply shocks on issuances, we show that instrumented equity capital inflows also predict increases in a variety of potential uses of funds: capital expenditures (CAPEX), corporate acquisitions, research and development expenses $(\mathrm{R} \& \mathrm{D})$, inventory accumulation, cash and short-term investments, and long-term debt reduction. ${ }^{4}$ We show that instrumented capital inflows lead large emerging market firms to significantly increase CAPEX. They also tend to lead firms to engage in more acquisitions, increase $\mathrm{R} \& \mathrm{D}$, accumulate inventories, hoard cash and short-term investments, and reduce long-term debt.

Second, to study the magnitude of the real investment consequences of issuances in emerging markets, we investigate the connection between issuances and uses of funds following the methodology developed by Kim and Weisbach (2008) and Erel et al. (2011).

\footnotetext{
${ }^{3}$ Because we employ instrumented inflows, we do not rely on lagging inflows for identification. However, by using lagged values of instrumented inflows, we reduce the likelihood that the relation between inflows and issuances reflects the response of inflows to increased demand for capital by issuing firms.

4 These are the six uses of funds analyzed by Kim and Weisbach (2008) and Erel et al. (2011).
} 
This approach explores how large firms use the funds raised in their equity offerings, while controlling for other sources of funding. We measure the increases in each use of funds over a four-year period. Our estimates indicate that the largest use of funds after the first year is CAPEX. For every million U.S. dollar raised in an offering, large firms as a group spend on average 700,000 U.S. dollars on investment four years after the issuance. This effect takes place as firms use the additional cash and short-term investments accumulated during the issuance year.

Using a back-of-the-envelope calculation, our analysis indicates that every million U.S. dollars of foreign equity capital results in seasoned equity offerings that fund an increase of about 110,000 U.S. dollars of corporate investment. The 110,000 -dollar estimate is the result of 160,000 U.S. dollars of additional secondary equity issuance (in response to every million U.S. dollar of inflows) and 700,000 U.S. dollars of average additional spending on investment (for every million U.S. dollar of capital raised). We consider this a back-of-the-envelope calculation because there are potential influences not captured by the Kim-Weisbach methodology that could affect our estimates. ${ }^{5}$

In summary, our paper uses firm-level data to provide the first clear evidence that supply-side shocks to global investors' interest in emerging market equity produce large increases in new equity issues, which are used in large part to fund investment. We identify shocks through a novel procedure that measures changes in the attractiveness of other

\footnotetext{
5 As discussed in Section VII, on the one hand, the estimates we report are affected by a negative bias because, as we show, equity issuances that result from an increased supply of foreign funds also expand firms' capacity to issue debt, which fund additional investment. Because our estimation method holds constant the amount of debt issued, it effectively over-controls for the effects of equity issuance on investment. On the other hand, it could be that equity issuances that result from increases in the supply of funding result in smaller real investment per dollar of funding than equity issuances that result from increases in the demand for funding (e.g., increases in the opportunities enjoyed by firms). This could be a source of positive bias during the estimated window.
} 
countries to global investors. Equity issuance responds to these shocks and seems to be an important channel through which capital inflows affect real economic activity.

Our paper is related to several strands of the literature. First, there is a literature on how aggregate economic activity is affected by the liberalization and flow of equity capital (Henry, 2000a; Henry, 2000b; Alfaro et al., 2004; Bekaert et al., 2005; Kose et al., 2010). These papers show that equity inflows are associated with a boom in aggregate investment and higher economic growth of the recipient countries. However, we know relatively little about the channels through which equity inflows affect real economic activity. ${ }^{6}$ Our paper adds to this literature by studying for the first time the effects of capital inflows using issuance-level data. We show that supply-side changes in capital inflows allow firms to raise new financing and expand investment, which might be behind the patterns documented in this literature. Moreover, our paper shows that the effects are not uniform across types of firms. Capital inflows seem to reduce the cost of equity finance for large firms more than for other firms, which likely reflects the fact that differences in firm size is a proxy for differences in global investors' knowledge and interest in firms.

The literature has found it challenging to disentangle supply and demand influences when gauging the effects of capital inflows on financial and real economic activity in a multicountry setting. Examining the case of one country, using detailed firm-level data, Baskaya et al. (2017a) and Baskaya et al. (2017b) isolate supply-side influences on capital inflows. In this paper, we propose a novel set of instruments in a multi-country context to distinguish between supply-side and demand-side effects on capital inflows, and we find that the supply side is important.

\footnotetext{
${ }^{6}$ Mitton (2006) and Chari and Henry (2008) use firm-level data to study the effects of liberalizing equity markets on firms' operating performance and corporate investment. Alfaro et al. (2017) evaluate the effects of capital controls on firm-level stock returns and real investment using data from Brazil.
} 
Our paper also contributes to another literature that asks why firms issue equity and bonds geared toward foreign investors. Part of this literature has studied firms' issuance activity in international markets, characterizing which firms issue abroad and why. Foreign markets can offer benefits compared to domestic ones in terms of access to better financing conditions, greater visibility, and enhanced corporate governance, among others (Pagano et al., 2002; Benos and Weisbach, 2004; Doidge, 2004; Karolyi, 2006; Schmukler and Vesperoni, 2006; Claessens and Schmukler, 2007; Forbes, 2007; Doidge et al., 2009). ${ }^{7}$

Although this literature assumes that issuances abroad target foreign investors, it has not shown that facilitating foreign investor participation actually influences issuances. ${ }^{8}$ In practice, it is hard to track the influence of foreign investors on firm behavior because there are no data identifying the nationality of who buys each security. Data are available, however, on the change in net purchases by foreigners of each country's publicly traded firms' equity, which is our measure of equity capital inflows. Our approach to identification allows us to use those data to link foreign participation in equity markets with consequences for each country's equity issuances in domestic and foreign markets.

A separate literature (Pagano et al., 1998; Kim and Weisbach, 2008; Brown et al., 2009; Erel et al., 2011; Didier et al., 2015) analyzes how firms use new capital market financing from various sources. We complement this strand of the literature by linking the use of funds with inflows of foreign capital. In particular, we study how shifts in the supply of equity financing affect the use of funds by the emerging market firms that tend to raise capital when their

\footnotetext{
${ }^{7}$ Other papers argue that, as liquidity became more abundant in the aftermath of the global financial crisis of 2008-09, firms issued more foreign currency bonds to take advantage of carry-trade opportunities (Chui et al., 2014; Powell, 2014; Caballero et al., 2016; Bruno and Shin, 2017; Moreno and Serena Garralda, 2018).

${ }^{8}$ Forbes (2007) studies the effects of the "encaje" controls on capital inflows in Chile from 1991 to 1998. She finds evidence that imposing the encaje on equity inflows reduced aggregate equity issuances.
} 
country receives capital inflows. We also find that firms use the proceeds primarily to expand investment, aside from any activity geared toward retiring debt and accumulating cash.

The rest of this paper is organized as follows. Section II discusses the data sources. Sections III explains our empirical strategy. Section IV reports country- and firm-level results linking capital inflows and issuance activity. Section V reports instrumented results for the responses of issuances to supply-side factors. Section VI analyzes the relation between equity inflows and issuances of bonds, as well as the relation between bond inflows and the issuances of both bonds and equity. Section VII reports the use-of-funds analysis. Section VIII concludes.

\section{Data}

We collect data on capital inflows using balance of payments information from the International Monetary Fund (IMF). The IMF provides data on annual private gross capital inflows and outflows by category: foreign direct investment (FDI), portfolio equity, portfolio debt (bonds), bank credit, and others. We focus on portfolio equity inflows, defined as the difference between foreign purchases of domestic shares and foreign sales of domestic shares, which can occur either in domestic or international markets. They involve both the trades incurred during the issuance activity and those related to secondary market trading.

Equity (bond) inflows are positive (negative) when foreign investors purchase more (less) domestic securities than what they sell. Foreign retail investors and foreign institutional investors (such as mutual funds, pension funds, hedge funds, and sovereign wealth funds) are often behind the foreign purchases and sales of domestic shares. Those investors purchase both existing and newly issued shares. 
To verify that the relation we observe between equity capital inflows and equity issuances reflects influences that are specific to equity markets, we also use data on non-equity capital inflows, including other categories of capital inflows to the private sector (FDI, portfolio debt, and other debt investments in banks and other sectors, excluding general government and central banks), which are in fact positively correlated with equity inflows.

Our sample consists of the 25 emerging market countries included in the MSCI Emerging Markets index during the 26-year period 1991-2016. ${ }^{9}$ The countries are: the Arab Republic of Egypt, Argentina, Brazil, Chile, China, Colombia, Czech Republic, Hungary, India, Indonesia, Israel, Jordan, Malaysia, Mexico, Morocco, Pakistan, Peru, the Philippines, Poland, the Republic of Korea (or South Korea), the República Bolivariana de Venezuela, the Russian Federation, South Africa, Thailand, and Turkey.

We focus mainly on positive equity inflows, which represent more than $84 \%$ of all inflow observations. Our focus on positive inflows reflects our goal to analyze whether firms issue more equity after foreign capital is invested in them, and how those equity proceeds are employed. Negative capital inflows, on the other hand, represent a departure of foreign capital. Although it is conceivable that firms might repurchase equity when foreign capital departs their country (a negative issuance), existing empirical evidence finds no connection between outflows and investment behavior by publicly traded firms, which suggests that negative issuance is not a common response to outflows. ${ }^{10}$ Our issuance data (explained below) do not

\footnotetext{
9 The MSCI index is a stock market index covering 25 emerging market countries representing $10 \%$ of global stock market capitalization. The index is maintained by MSCI Inc., formerly Morgan Stanley Capital International, and is used as a common benchmark for international equity mutual funds (Raddatz et al., 2017).

10 Tong and Wei (2010) and Claessens et al. (2012) investigate stock price reactions and real investment changes associated with the large capital outflows produced by the global financial crisis. They find a significant negative effect on stock prices, but no effect on investment. That finding is consistent with firms not responding to capital outflows and lower stock prices with significant repurchases of their shares.
} 
provide information on stock repurchases, so we focus on the positive issuance implications of positive capital inflows. However, for robustness, we analyze the effects of negative inflows on equity issuance. Our findings confirm the view that negative equity inflows have no significant effects on equity issuance. ${ }^{11}$

The data on equity and bond issuance activity come from the Thomson Reuters Security Data Corporation Platinum database (SDC Platinum). This database provides transaction-level information on new issuances of common equity by publicly traded firms. The transactions in the database include 20,306 SEOs. The database also includes transactions related to initial public offerings (IPOs), which we do not use except when explicitly indicated. Because the database covers the universe of issuance transactions, we assume zero issuance activity for the firm-year observations when no positive transactions are recorded for a given publicly listed firm in a given year (as is common in the finance and trade literatures that work with transaction-level data). A firm enters the sample since its IPO year. We obtain the aggregate issuance data by adding all the transactions for firms in each country-year.

In both our aggregate and firm-level regression analysis we focus on SEOs for two reasons. First, our firm-level regression analysis employs lagged information about firms, including the lagged market value of equity, which is only available for firms that were publicly traded in the prior period. To ensure comparability with our firm-level estimates, we exclude IPOs from our aggregate analysis. Second, we wish to understand how publicly traded firms' issuance decisions respond to foreign investor interest. Including initial offerings would mix two different phenomena: the responses of private firms (which choose to become public)

\footnotetext{
${ }^{11}$ Specifically, we find that negative inflows tend to produce an asymmetric response in equity issuance. Because negative inflows reduce issuances only slightly, even large negative inflows are still associated with large positive issuances.
} 
with the responses of preexisting publicly traded firms. In results not reported here, we find that our aggregate results remain unchanged if we include IPOs in our sample.

The data include issuances in international and domestic equity markets. ${ }^{12}$ Equity issuances are sold to a combination of domestic and foreign investors. We have data on a total of 12,723 firms and a total of 330,798 firm-year observations. We include both financial and non-financial firms. Each group has a significant share of the issuance activity. The issuance activity of financial firms is relevant for the financing of investment by non-financial corporations, although financial firms do not directly engage in capital investment. In Appendix Tables 1, 5, and 6, we show that the results on issuance activity are robust to excluding financial firms from our sample.

The sample of firms used is a result of merging the SDC data with Thomson Reuters Worldscope data, which provide information on firms' financial statements (balance sheets, income statements, and cash flow statements) for publicly listed firms. We need this information both to classify firms as large and for the use-of-funds analysis. After matching the two sources, Worldscope data are available for publicly listed firms and for $70 \%$ of the equity issuers contained in the SDC database of the 25 emerging markets under study. The information on market value of equity, which we use to classify firms by size, is available from the IPO year onward.

Table 1 reports summary statistics of issuance activity by country. Column 1 reports the number of firms included in the sample. Columns 2 and 3 show the average annual value of equity issuance proceeds for all firms in a country and the value of proceeds per firm, respectively. In a typical year, the average firm in the sample (including issuers and non-issuers)

\footnotetext{
12 An issuance is classified as international if the firm's country of origin is different than the country where the equity is raised. SDC classifies the majority of newly issued shares that are destined to become depository receipts (including American Depositary Receipts and Global Depositary Receipts) as international issuances.
} 
issues equity worth 6 million U.S. dollars. Because most firms are not actively issuing equity every year, the value of proceeds per issuing firm is much larger.

\section{Empirical Strategy and Identification}

Our presentation of empirical findings begins with ordinary least squares (OLS) results at the country level. The results show a strong empirical relation between country-level equity inflows and seasoned equity issuances. These results do not provide a causal interpretation of the links between issuances and equity inflows, but they do document an important new fact: increases in equity inflows are associated with increases in equity issuance, and that is true after controlling for country and time fixed effects.

The country-level results do not permit a causal interpretation because they do not distinguish between supply-side and demand-side influences. Supply-side factors include increased global liquidity or global appetite for risk (depending on each country's sensitivity to those global shocks), or idiosyncratic changes in foreign appetite for investing in particular countries, which could reflect changes in constraints on international investments, improvements in a destination country's property rights, or legal institutional improvements (Stulz, 2005; Karolyi, 2015). Demand-side factors are any changes that affect investment opportunities, such as changes in productivity, technology, or local economic conditions. For example, improvements in firm productivity within the subject country might drive both equity inflows and issuances. In that case, although foreign investors' willingness to provide equity inflows could facilitate adjustment to demand-side shocks (by reducing the cost of issuances), changes in foreigners' interest in investing might not be an important source of change in either inflows or issuances. Several papers document that supply-side factors have 
been more important than demand-side factors in explaining capital inflow episodes in emerging economies (Forbes and Warnock, 2012; Fratzscher, 2012; Avdjiev et al., 2018).

In theory, analyses of the relation between equity valuations and capital inflows could shed light on the factors behind our initial OLS results. Increased foreign investors' holdings of stock in a country could reflect supply-side influences (changes in investors' preferences) or demand-side changes (perhaps due to new opportunities) that lead firms to increase the number of shares available for purchase. Supply-side increases in funding imply a reduction in investors' required future returns, and a contemporaneous increase in stock prices. Therefore, if capital inflows reflect supply-side influences, one should expect that capital inflows are associated with increases in contemporaneous stock prices and diminished expected stock returns. If instead inflows rise due to shifts in the demand for capital by firms, the greater demand for funds would tend to induce higher required expected returns by investors, and therefore lower contemporaneous stock prices, ceteris paribus. Thus demand-side and supplyside shocks have different implications for the path of stock prices.

Although in principle the association between equity inflows and equity prices would be interesting for us to study, in practice, identification is quite challenging when focusing on price changes because the timing of inflows is not measured precisely enough. ${ }^{13}$ Our measures of capital flows are annual, and our ability to instrument those capital flows to identify supplyside variation is therefore also annual. Given that supply (demand) shocks produce positive (negative) contemporaneous price changes and negative (positive) future returns, the inability to measure the precise timing of inflows is a fundamental problem. Furthermore, if supplyside shocks induce equity issuance, as we show they do, a further complicating factor is the

\footnotetext{
${ }^{13}$ Increased capital inflows generally are associated with higher asset prices (Kaminsky and Reinhart, 1999; Jansen, 2003; Chari and Henry, 2004; Hau and Rey, 2006; Reinhart and Reinhart, 2009; Kim and Yang, 2011; Tillmann, 2013; Olaberría, 2014; Chari et el., 2017).
} 
negative stock price reactions that accompany the announcement of an equity offering, which will at least partially offset the initial positive price effect (Asquith and Mullins, 1986).

In this paper, we focus on low-frequency connections between equity inflows and equity issuances. We employ IV estimation to disentangle demand-side from supply-side effects in explaining the relation between capital inflows and equity issuances. A valid instrument should be strongly correlated with capital inflows and should also satisfy the exclusion restriction that it is not correlated with demand-side influences within the subject country. We make use of the fact that, for a given amount of capital inflows to emerging markets as a whole, positive shocks to other countries' attractiveness to foreign investors constitute negative shocks to the subject country's supply of funds. Our instrument captures changes in the attractiveness to foreign investors of other emerging market countries (for a given total amount of inflows, which we capture by a time fixed effect). ${ }^{14}$

We employ two alternative measures of the attractiveness of other countries to equity investors. Our alternative measures of the attractiveness of other countries are the aggregate value of equity in other emerging market countries, and the volume of equity issuances in other emerging markets. Both of these measures are orthogonalized with respect to the subject country's values of these variables, removing any source of comovement that might be attributable to demand-side influences (as has been shown to be potentially important by Forbes and Warnock, 2012; Ahmed and Zlate, 2014).

Although the orthogonalized market value of equity, or orthogonalized issuances, in other countries reflect a mix of supply- and demand-side influences within those other

\footnotetext{
${ }^{14}$ For example, Brazil introduced capital controls in 2006, which decreased the attractiveness of Brazil to foreign investors. Forbes et al. (2016) show that foreign investors increased their portfolio allocations to other emerging countries seen as sharing some type of similarity with Brazil, such as Chile. This constitutes a positive shock to Chile's supply of funds, unrelated to Chile's fundamentals.
} 
countries, from the standpoint of the subject country, they are exogenous influences on the supply of funding. If orthogonalized increases in the value or volume of issuances in other countries are responsive to capital inflows into those other countries (as our aggregate results suggest), then from the standpoint of the subject country, the diversion of capital inflows into other countries is a negative capital supply shock. For illustrative purposes, Figure 2 plots Mexico's equity inflows against the equity value of other countries than Mexico (Panel A) and against the equity issuances of other countries (Panel B). Both instruments are negatively correlated with equity inflows.

Even before employing our instrumenting, one could argue that firm-level differences in the magnitude of the connection between capital inflows and issuances are indicative of a supply-side story. If demand-side influences are largely common across firms of different sizes, then greater issuance responses to capital inflows for large firms likely reflect supply-side differences resulting from differential access to international investors. From that perspective, even our firm-level OLS analysis, which controls for firm and year fixed effects, and which displays a stronger association between equity inflows and issuance for large firms, is suggestive of supply-side influences. ${ }^{15}$

Furthermore, the relation between inflows and issuances is evident for lagged inflows as well. A positive relation between lagged inflows and issuances also suggests a supply-side influence whereby equity inflows put upward pressure on stock prices, which reduces the cost of equity capital, encouraging destination countries' firms to issue equity, a decision that occurs with a lag.

\footnotetext{
15 In a prior version of this paper (available as NBER Working Paper 24433), we sorted firms by size according to the average size of their issuances over the sample period and obtained similar results.
} 
Although differential effects for large and small firms and observed connections between lagged inflows and subsequent issuances are both suggestive of supply-side causation, these facts by themselves are not conclusive. It is conceivable that demand-side influences might differ across firms of different sizes. And serial correlation in demand shocks could produce a relation between lagged inflows and current issuances. For these reasons, although we believe that all of the various pieces of evidence point toward a supply-driven story, we do not rely only on firm-level differences or lags for identification, but emphasize our instrumenting of equity inflows.

\section{Equity Inflows and Issuances}

\section{A. Capital Inflows and Issuance Activity in the Aggregate}

As explained in the Introduction, Figure 1 displays the relation between global capital inflows and global equity issuance values. These two worldwide time series are significantly positively correlated: the correlation coefficient is $0.35 .{ }^{16}$ In Figure 3, we alternatively plot the time series of global equity inflows scaled by GDP and global equity issuances scaled by GDP.

To control for country and year effects, we estimate the following country-level panel regression:

$$
\log (1+\text { Issuance })_{c t}=\alpha_{c}+\alpha_{t}+\beta \log (\text { Inflows })_{c t}+\varepsilon_{c t}
$$

where Issuance $_{c t}$ denotes the value of seasoned equity issuance proceeds (in million U.S. dollars) by all firms of country $c$ in year $t$ and Inflows $c t$ refers to equity capital inflows (in million U.S. dollars) received by country $c$ in year $t$. We use the log of issuance plus one (million

\footnotetext{
16 Appendix Figure 1 reports aggregate patterns that include both IPOs and SEOs. The fluctuations over time are similar to those that use only SEOs, but the size of the value of issuance activity is substantially greater when IPOs are included.
} 
U.S. dollars) to account for country-year observations with zero issuances (15\% of the total). $\alpha_{c}$ and $\alpha_{t}$ capture country and year fixed effects, respectively. We cluster standard errors of this regression, and all other analogous regressions reported below, by country and year. ${ }^{17}$

Table 2 shows a highly significant positive relation between capital inflows and country-level issuance proceeds in emerging markets. Column 1 shows that the elasticity of issuances to inflows is $0.52{ }^{18}$ This indicates that inflows imply more than a simple transfer of equity ownership from domestic to foreign investors. The result implies that for the typical country in a typical year, every million U.S. dollars of equity capital received from foreign investors is associated with an increase in the value of seasoned equity proceeds of 160,000 U.S. dollars. ${ }^{19}$

To make sure that our results are not affected by the log specification, which excludes negative inflows, we re-estimate Equation (1) scaling country issuances and all equity inflows (positive and negative) by GDP. Column (2) of Table 2 reports the results of this alternative specification. Increases in capital inflows, relative to GDP, are strongly correlated with greater equity issuances, relative to GDP.

We also report results separately for positive and negative equity inflows relative to GDP in Columns (3) and (4) of Table 2. Interestingly, the coefficient magnitude for negative inflows is much smaller and statistically insignificant, suggesting only a small reduction in

\footnotetext{
${ }^{17}$ Our results remain unchanged if we cluster standard errors at the country level.

${ }^{18}$ In Appendix Table 1, Column (2), we re-estimate Equation (1) using as dependent variable the sum of SEOs and IPOs. The results remain unchanged, while the dollar effect increases to 300,000 U.S. dollars raised for every million U.S. dollar of inflows. In Appendix Table 1, Column (3), we re-estimate Equation (1) excluding financial sector firms from our sample. Again, the results do not change.

19 To calculate the dollar effects, we first calculate the predicted equity issued for each country-year pair by replacing the corresponding equity inflows into Equation (1) and using the estimated coefficients from the regression results. As fixed effects, we use the coefficients for each year and country for the corresponding country-year pair. We then increase equity inflows by one million U.S. dollars and repeat the procedure, which yields the new predicted issuance. Next, we compute the difference between the two predicted values. For each country, we take the median of the differences across all years and report the value for the median country.
} 
issuances, which remain positive, even when capital inflows are highly negative. Given this asymmetry in the relation between equity inflows and aggregate issuances, we focus on positive equity inflows in our empirical analysis of the effects of equity inflows on issuance decisions at the firm level. ${ }^{20}$

\section{B. Capital Inflows and Firms' Issuance Activity}

To analyze the impact of equity capital inflows on firms' issuance activity, we estimate a firmlevel panel regression accounting for firm and year fixed effects:

$$
\log \left(1+\text { Issuance }_{i c t}=\alpha_{i}+\alpha_{t}+\beta \log (\text { Inflows })_{c t}+\varepsilon_{i c t},\right.
$$

where Issuance $_{i c t}$ is the value of seasoned equity raised (in million U.S. dollars) by firm $i$ in country $c$ in year $t$. Firms issue equity sporadically, so firm issuances exhibit lumpy behavior. As in the previous section, we add a one (million U.S. dollars) to the log of issuances to account for firm-year observations with zero issuances. $\alpha_{i}$ and $\alpha_{t}$ denote firm and year fixed effects, respectively.

Table 3 reports the results. Interestingly, Column (1) shows that the effect of capital inflows on firm-level issuance is only weakly statistically different from zero on average for the whole sample of firms. To explore the heterogeneity that could be driving the aggregate results, we divide the sample of equity issuers into two groups: large firms (those in the top decile of size, as measured by the prior period's market value of equity within a country and

\footnotetext{
${ }^{20}$ One can explain this finding from the perspective of corporate capital structure decisions: firms in emerging markets have strong incentives to issue equity when the cost of doing so is low, but they do not have to reduce outstanding equity when foreign withdrawals of equity cause prices to fall. Given the high costs of external finance in emerging markets, firms in these economies tend to have highly productive unrealized investment opportunities (from a Tobin's q perspective), which explains why issuances tend to be positive even when inflows are small or negative, and why repurchases of equity are rare.
} 
year) and other firms. ${ }^{21}$ We lag firms' market value of equity by one year to ensure that our measure of firm size is unaffected by current-year capital inflows. In Column (2) of Table 3, we find that while the average effect for all firms is not statistically significant, large firms display a highly significant positive differential response to equity inflows. In Column (3), we replace firm and year fixed effects with firm and country-year fixed effects. ${ }^{22}$ This specification allows us to control for all time-varying country shocks. The coefficient of interest is identified purely from the within-country variation between large and small firms. The differential response of large firms remains positive, statistically significant, and of nearly identical value as in Column (2).

Columns (4) and (5) of Table 3 report results that are the same as those in Columns (2) and (3), except that lagged inflows are used in place of contemporaneous inflows. Results are similar in magnitude and statistical significance. ${ }^{23}$ In results not reported here, we also checked to see whether the responses of firms issuing in foreign markets are different from those of large firms issuing in domestic markets and we found that they are rather similar.

In Table 4, we examine how our coefficient estimates for large firms' equity issuances change as the definition of a large firm varies. In Panel A of Table 4, we report specifications identical to Column (3) of Table 3, where we vary the percentile cutoff that defines large firms. Panel B is identical in structure except that it uses lagged equity inflows instead of contemporaneous. In both Panels $\mathrm{A}$ and $\mathrm{B}$, as the percentile cutoff becomes less selective (more firms are included), the coefficient declines monotonically in value. From the first to

\footnotetext{
${ }^{21}$ We estimate the regression: $\log (1+\text { Issuance })_{i c t}=\alpha_{i}+\alpha_{t}+\beta \log (\text { Inflows })_{c t}+\gamma \log (\text { Inflows })_{c t} \times$ Large Firm ict-1 $_{\text {ict }}+$

22 The effect of capital inflows, which varies at the country-year level, is absorbed by the country-year fixed effects. The equation for the new specification with interacted country-year fixed effects is: $\log (1+$ Issuance $_{i c t}=\alpha_{i}+\alpha_{c t}+\gamma \log (\text { Inflows })_{c t} \times$ Large Firm $_{\text {ict }-1}+\varepsilon_{\text {ict }}$.

${ }^{23}$ In unreported results, we run specifications including both contemporaneous and lagged inflows. The point estimate for contemporaneous inflows remains unchanged, however due to the autocorrelation of inflows it is difficult to infer from these estimates the relative importance of the effects of inflows at different times.
} 
the fourth decile, the declines indicate that the incremental decile of firms displays a smaller, but still positive, response than firms in more selective deciles. After the fourth decile, the response of incremental firms (those in the fifth decile) is zero. Nonetheless, our purpose is not to model the responsiveness of each size category, but rather to explore important differences in behavior between large and small firms. For that purpose, a cutoff that distinguishes large from small is useful, and the results in Table 4 show that it does not matter much whether one picks the first, second, third, or fourth decile when defining large firms.

The precision of estimates, however, is highest at the first decile of largest size, and partly for that reason, we prefer to use that definition. Furthermore, as we show in Appendix Table 2, there are a priori reasons to prefer the first decile as the definition of large firms. On average, the firms that choose to list issues abroad tend to be within the largest $12^{\text {th }}$ percentile of firms. Those listed in the MSCI Index tend to be within the largest sixth percentile. These are two a priori indicators of firms that have access to foreign investors, one more selective than the other. Thus, we conclude that the firms in the top decile of firm size, which issue either abroad or in the domestic market, are large enough to be of interest to foreign investors.

\section{Instrumental Variables Approach}

As discussed in the Introduction and in Section III, an increase in issuance activity could reflect an increase in foreign equity funding supply or domestic equity funding demand, or some combination of the two. This section analyzes the importance of the supply-side channel and whether it can explain the response, documented in the previous section, of the issuance activity of a large firms to equity inflows. To do so, it presents our IV regressions, which 
identify supply-side shocks affecting capital inflows. ${ }^{24}$ We report our IV results for issuances

in Tables 5 and 6. Panel A of each of these tables employs contemporaneous equity inflows, whereas Panel B employs lagged equity inflows. Standard errors are bootstrapped and clustered both by country and by year. ${ }^{25}$

As discussed in Section III, the orthogonalized market value of other countries' equity, and the orthogonalized equity issuances of other countries, offer alternative measures of the attractiveness of the subject country's equity market to foreign investors. The advantage of those alternative instruments is that both of them affect the equity capital inflows that a subject country experiences exclusively through external influences.

We orthogonalize the market value of other countries' equity and other countries' equity issuances by removing the covariance of each of them with the subject country. That is, to orthogonalize the market value (equity issuances) of other countries, we regress the total market value of equity (equity issuances) of all emerging markets on the subject country's market value of equity (equity issuances), and then use the residuals as our instrument. ${ }^{26}$

\footnotetext{
${ }^{24}$ The structure of our model combines aggregate country-level data in the first-stage regressions and firm-level data in the second-stage regressions. To account for most of the variation in the data, we use country and year fixed effects in the first-stage regressions and firm and country-year fixed effects in the second-stage regressions. However, the main results remain unchanged if we use the same firm-level structure of the data and the same set of fixed effects in the first- and second-stage regressions.

${ }^{25}$ To account for the fact that we use an estimated regressor in the second stage, we bootstrap the standard errors. Our approach follows the methods outlined in Cameron et al. (2006), Cameron and Trivedi (2009), and Cameron et al. (2015) and adapts them to our data structure, clustering separately at the country and year level and then computing standard errors that take into account the two-way (country and year) clustering. The bootstrapped standard errors are obtained jointly for the two stages, for each clustering level. We obtained similar results when we estimated the model by bootstrapping the standard errors drawing independent samples in each stage. We report results with 1,000 sample draws for each clustering level.

${ }^{26}$ The orthogonalized market value $\varepsilon_{-} \overrightarrow{m v}_{c t}$ for country $c$ in year $t$ is constructed as the residual of the following regression: $\log (\text { MVem })_{t}=\beta \log (\text { MVown })_{c t}+\varepsilon_{c t}$, where $M V e m_{t}$ is the sum of all 25 emerging markets' value of market capitalization in year $t, M V O w n_{c t}$ is the value of own market capitalization for country $c$ in year $t$, and $\varepsilon_{-} m v_{c t}$ is the residual to be predicted. The orthogonalized issuance volume is calculated in the same way. For each instrument, 25 time-series regressions are estimated separately for each country. Country values of market capitalization are downloaded from the World Bank's WDIs.
} 
Column (1) of Tables 5 and 6 shows that both measures of our instrument are powerful negative predictors of equity capital inflows in the first-stage regressions.

The second-stage coefficients in Tables 5 and 6 (Column 2) are slightly smaller or equal in magnitude, but not statistically different, than the comparable OLS coefficients reported in Table 3. In the absence of measurement error of capital inflows, the OLS coefficient should be greater than or equal to the IV coefficient because OLS captures supply and demand effects and those effects are additive. Our results are consistent with that expectation. The equality of the magnitude of the OLS and IV coefficient suggest that supply-side influences account for most of the variation in equity capital inflows. However, there is reason to believe that equity inflows are measured with error, which biases the OLS coefficient downwards, implying that the true OLS coefficient is probably larger than the estimated value. ${ }^{27}$ In the absence of measurement error, a larger OLS coefficient would suggest that demand-side influences also are present.

Overall, we find that whether one measures the attractiveness of other countries' equity markets to foreign investors using other countries' orthogonalized market value or other countries' orthogonalized equity issuance volume, the results are similar: supply-side effects of instrumented equity inflows are large and statistically significant. Results are robust to using lagged or contemporaneous values of instruments. The results are also robust to using the non-orthogonalized market value of other countries equity or the non-orthogonalized issuance volume of other countries (these results are not reported here). We conclude that

\footnotetext{
27 As Lane and Milesi-Ferretti (2017, p. 21) note in their discussion of the capital inflow data: "One concern ... is the increasing difficulty in properly assessing external exposures ... particularly in light of the size of crossborder asset trade intermediated by financial centers [which complicates the measurement of inflows into a particular country] ... This difficulty affects virtually all categories of cross-border holdings ..." As a result, under the assumption that our identification is correct, the OLS coefficient in our setting could be larger or smaller than the IV estimate.
} 
supply-side shocks are an important driver of equity capital flows, and that exogenous changes in the supply of foreign equity inflows have important consequences for equity issuances by large firms.

Lastly, we consider the robustness of our results to adding additional macroeconomic control variables to our first-stage regression. We conduct this test because our first-stage regression captures variation at the country-year level, while our second-stage regression captures variation at the firm-year level. That difference gives rise to a potential concern. Usually, when instrumenting, all the control variables in a second-stage regression are included also in a first-stage regression. In our case, it is not possible to include the country-year fixed effects from our second-stage regression in our first-stage regression, where the dependent variable is an aggregate for each country-year. The potential concern is that relevant macroeconomic influences that affect country-year variation are omitted from the first-stage regression, which could lead us to overstate the influence of our instruments on equity inflows. We address this potential problem by adding additional macroeconomic controls to our firststage regressions, which are reported in Table 7 . We note that other papers in the literature that follow this same methodology for instrumenting simply maintain different sets of fixed effects or controls due to the different nature of the data in the first and second stages (KaracaMandic and Train, 2003; Petrin and Train, 2003, 2010; Oberholzer-Gee and Strumpf, 2007).

We include three macroeconomic controls in these first-stage regression specifications: non-equity capital inflows, GDP growth, and the current account balance as a fraction of GDP. These variables capture macroeconomic influence that could affect equity inflows but that are unrelated to shifts in equity investors' supply of funds. For example, an improvement in a country's terms of trade could lead, ceteris paribus, to an expansion in its current account surplus, an increase in GDP growth, and a reduction in capital inflows. We 
report results for both lagged and contemporaneous specifications of our regressions using orthogonalized equity value as the instrument. We obtain similar results when using orthogonalized issuance volume, which are reported in Appendix Table 3.

The results in Table 7 and Appendix Table 3 show that when these three controls are included, either separately or together, they sometimes are significant forecasters of equity capital inflows. However, the inclusion of the controls has little effect on the coefficients for our instruments in the first-stage regression, and no effect on the coefficient values or the statistical significance of those coefficients in the second-stage regressions. We conclude that the exclusion of country-year fixed effects from our first-stage regression is not a source of important estimation bias in our framework.

\section{The Endogeneity of Bond Issuances to Equity Flows}

Whereas our focus is on the effect of instrumented equity inflows on equity issuances, in this section, we also consider additional results for bond inflows and bond issuances, which we report in Table 8, using the orthogonalized market value of equity as an instrument. As in Tables 5 and 6, we report regressions using both contemporaneous and lagged values of instrumented variables. In Appendix Table 4, we report analogous results using orthogonalized equity issuance volume as the instrument. Those results are similar to those in Table 8 , and in our discussion of these results, we will only refer to the results in Table 8.

We are interested in bond inflows and bond issuances for three reasons. First, as a further test of the validity of our instrumenting procedure, it is interesting to ask whether instrumented bond inflows (using the same two instruments we employ in Tables 5 and 6) have similar effects on bond issuances as the effects on equity issuances we measure in Tables 
5 and 6. In Columns (1) and (2) of Table 8, we show that there is indeed a similar relation between instrumented bond inflows and bond issuances.

Second, one might worry that bond inflows that are correlated with our instruments, rather than equity inflows per se, could be driving the observed relation between instrumented equity inflows and equity issuances. Whereas it is true that our instruments are correlated negatively with bond inflows, as is apparent in Column (3) of Table 8, we show in Column (4) that there is no connection between instrumented bond inflows and equity issuances. Instrumented bond inflows are not causing equity issuances.

Third, in Section VII, we analyze the investment consequences of equity issuances. However, if instrumented equity inflows produce both equity issuances and bond issuances (perhaps through the positive effect of equity issuances on firms' debt capacity), then the KimWeisbach method for estimating the investment consequences of equity issuances in Section VII should be regarded as conservative because it ignores the additional effect on investment from the bond issuances that result from the expanded debt capacity produced by equity issuances. We find in Column (6) that bond issuances are, in fact, positively predicted by instrumented equity inflows.

\section{Capital Inflows and Uses of Funds}

Having established a connection between equity capital inflows and equity issuances, we now study the real effects of capital equity inflows. Following the approach of Kim and Weisbach (2008) and Erel et al. (2011), we focus on six uses of funds: CAPEX, acquisitions, R\&D, inventory accumulation, cash accumulation, and long-term debt reduction. ${ }^{28}$ Our analysis

\footnotetext{
${ }^{28}$ We obtain the variables CAPEX, acquisitions, R\&D, and long-term debt reduction from the income and cash flow statements and the variables inventory accumulation and cash accumulation from the balance sheets.
} 
proceeds in two steps. First, to establish the connections among exogenous changes in the supply of funds and firms' decisions to use equity issuance proceeds, we estimate (in Table 9) the effect of instrumented capital inflows on the various potential uses of funds. This approach has the advantage of establishing a causal connection between exogenous variation in the supply of funds and endogenous asset accumulation by firms. But its weakness is that it does not explicitly connect endogenous issuance and investment responses. To address that question, we study how large firms use the funds raised in their equity offerings, and we report those results in Table 10. In Appendix Tables 5 and 6 we show that we obtain nearly identical results for a subsample that is restricted to non-financial firms. This reflects the fact that nonfinancial firms comprise most of our sample (representing almost $90 \%$ of our observations).

Table 9 reports the results of estimating the effects of equity capital inflows separately on each use of funds, for both contemporaneous and lagged inflows. We report IV results, using other countries' orthogonalized market value as our instrument. We obtain similar results when using other countries' issuance volume (we report those alternative results in Appendix Table 7). Column (1) of Table 9 shows that equity inflows lead to a significant increase in capital expenditures by large firms. Columns (2) and (3) show that, after the arrival of equity inflows, large firms also tend to undertake more corporate acquisitions and invest more in R\&D. The final three columns of Table 9 show that increased equity inflows lead to inventory accumulation, cash accumulation, and a reduction in long-term debt.

The results in Table 9 show the connections between capital inflows and different uses of funds, but the analysis does not link the uses of funds to the actual equity issuances. Another approach to analyze the linkages among issuances and uses of funds, which removes the effect of funding sources other than equity, is the methodology of Kim and Weisbach (2008) and 
Erel et al. (2011), reported in Table 10. This method has the important advantage of measuring investment uses of funds from firms as a consequence of their actual equity issuances.

There are two potential sources of bias in using these estimates to measure the effects of exogenous changes in funding supply. On the one hand, because this method holds the amount of bond issuance constant, it ignores the spillover effect of instrumented equity inflows on bond issuances, which Section VI shows are positive. From that perspective, the estimates reported in Table 10 underestimate the investment consequences of an increase in the supply of equity funds. On the other hand, there is also a possible source of an offsetting positive bias in the estimates reported in Table 10. It is possible that obtaining the proceeds from equity issuances that result from increases in the supply of funds have smaller observable effects on investment than when issuances are a consequence of increases in the demand for funds. Firms might take advantage of times of cheap funding to raise funds even if they do not have any projects worthy of immediate funding, which would lead firms to accumulate more of the proceeds as cash. Those funds could be used for investment at a later period, outside our window of estimation. ${ }^{29}$ Therefore, we regard these coefficient estimates in Table 10 as back-of-the-envelope calculations rather than precise estimates.

We focus on the six uses of funds described above, measuring the change in each use of funds over a variety of time intervals, ranging from one year to four years. Following those authors, we begin by calculating the use of funds after each firm's equity offering (whether caused by capital inflows or something else) by estimating the following regression for the equity offerings of large firms:

${ }^{29}$ Calomiris et al. (2019) find evidence that emerging market bond issuances spurred by reductions in the cost of issuing bonds after 2009 tend to result in lower than average investment relative to proceeds and a higher than average proportion of cash accumulation. Similarly, in results not reported here, when we re-estimate the analysis of the use of equity issuance proceeds separately for the pre-2009 and post-2009 subsamples in Table 10, we find that investment rates are somewhat lower in the post-2009 subperiod. 


$$
\begin{aligned}
Y_{i c t}=\alpha_{c}+\alpha_{t} & +\beta \log \left[1+\left(\frac{\text { Issuance }}{\text { Assets }}\right)_{i c t}\right] \\
& +\gamma \log \left[1+\left(\frac{\text { OtherSources }}{\text { Assets }}\right)_{i c t}\right]+\delta \log \left[\text { Assets }_{i c t}\right]+\varepsilon_{i c t},
\end{aligned}
$$

where $Y=\log \left[\left(\sum_{i=1}^{n} V_{i} /\right.\right.$ Assets $\left.)+1\right]$ for the income- and cash flow-statement items $(V=$ CAPEX, acquisitions, R\&D, long-term debt reduction), and $Y=\log \left[\left(\left(V_{t}-V_{0}\right) /\right.\right.$ Assets $)+$ 1] for the balance-sheet items ( $V=$ inventory, cash holdings). $N=1,2,3,4$ denotes the years following the issuance. Assets denotes total assets in the year just prior to the equity issuance $(n=0)$. Other sources $=\log \left[\left(\frac{\sum_{i-1}^{n}\left(\text { Total sources }_{i}-\text { Issuance }\right)}{\text { Assets }}\right)+1\right]$, where total sources of funds represent the total funds generated by the firm internally and externally during a given year.

Table 10 reports the results of estimating Equation (5) separately for each use of funds, for each time interval considered. We report the estimated elasticities and also the dollar effects, for the average firm of the typical country in a typical year. ${ }^{30}$ The table shows that for every million U.S. dollars raised in an offering, large firms increase CAPEX on average by 180,000 U.S. dollars in the year after the offering. The effect on CAPEX increases to 700,000 U.S. dollars when the equation is estimated over a four-year period. After four years, issuers spend about 150,000 U.S. dollars in acquisitions. The effect on R\&D is not statistically significant when we include all firms but becomes significant when we exclude financial sector firms (Appendix Table 6). Overall, the largest use of funds is CAPEX. Firms also spend some

\footnotetext{
${ }^{30}$ To calculate the dollar effects, we first calculate the predicted values of the dependent variables for each firmyear observation by plugging the actual values of firm issuances, other sources of funds, and total assets into Equation (5). For the fixed effects, we use the coefficients for each year and country of the corresponding country-year pair. We then re-calculate the predicted values of the dependent variables after adding one million U.S. dollars to the issuance value. Next, we calculate the difference of the two predicted values for each firmyear observation. To aggregate the differences, we first take the time-average of the differences per firm, we then take the median firm-average per country and subsequently the median country in our sample.
} 
of the equity proceeds in accumulating cash and short-term investments. This effect is largest in the first year that the firm issues, then (similar to the findings in Kim and Weisbach, 2008) it diminishes markedly and becomes statistically not significant after four years of the issuance activity. The effect on long-term debt reduction is not significant at any horizon. The fact that

firms spend most of the issuance proceeds to fund corporate investment suggests that capital inflows reduce equity financing costs. The result provides evidence against alternative explanations for equity issuance, such as market timing (Baker and Wurgler, 2000).

Overall, our results indicate that equity issuance is an important channel through which capital inflows can affect real economic activity. In the aggregate analysis, we documented that one million U.S. dollars of equity inflows was associated with an increase of 160,000 U.S. dollars of country-level seasoned equity issuances. On the other hand, in this section we have shown that large firms invest on average 700,000 U.S. dollars of each million raised in an equity offering. Combining both results, a back-of-the-envelope calculation indicates that for every million U.S. dollars of equity capital received from foreign investors, emerging market firms use the proceeds of seasoned equity offerings to increase corporate investment by at least 110,000 U.S. dollars ( $=0.16 \times 0.7$ for every million U.S. dollar received).

\section{Conclusions}

There is a growing literature documenting that greater capital inflows are associated with important increases in aggregate investment and higher economic growth. A separate large literature studies the issuance activity of firms. We seek to determine whether increases in equity capital inflows into emerging market countries are associated with increases in equity issuance and corporate investment by publicly traded firms, and whether any observed association can be attributed to supply-side influences from exogenous changes in 
international investors' interest in investing in particular countries. This paper is the first study to use issuance-level data to document the connections between supply-side shocks to capital inflows and firm-level responses in equity issuance and investment. By connecting all three elements, we provide clear evidence linking changes in the supply of global funds with real economic activity consequences in emerging market countries.

We find that increases in equity inflows into emerging markets are associated with higher values of country-level equity issuance proceeds. This indicates that inflows imply more than a simple transfer of equity ownership from domestic to foreign investors. Using firmlevel data, we show that large firms disproportionately drive this relation. Instrumenting equity inflows (both contemporaneous and lagged) with various alternative measures that capture the exogenous variation in other countries' attractiveness to foreign investors, we show that our results are driven by variation in foreign equity capital supply.

Lastly, we find that equity capital inflows lead large firms to increase corporate investment. We also show that large firms invest, on average, a substantial fraction of the funds raised in equity offerings. Our evidence is consistent with capital inflows lowering equity financing costs, which allows firms to raise funds to finance new investments. More generally, our results indicate capital inflows affect real economic activity through equity issuance activity, among other possible channels.

Our work shows how micro data can provide unique insights into how subsets of firms drive aggregate relations. Our findings suggest that the issuance and investment behavior of large firms in emerging markets is highly responsive to equity inflows. But apparently, many other emerging market firms are not the target of global market investors' share purchases. For those smaller firms, large flows of funds connecting their countries to global markets have little direct effect on their propensity to issue equity. This suggests that it can be useful to 
divide firms in emerging economies into two categories: those for which equity capital inflows have significant and important direct effects on the cost of issuing capital, and those for which they have little effect.

To the extent that equity inflows lower the cost of finance for large firms, that may create a competitive advantage for those firms. At the same time, it is possible that large firms may share some of the benefits of their access to international investors with other firms. Other firms could benefit indirectly from more abundant trade credit, or increased demand for their products and services. Also, if equity issuances reduce issuers' demands for local bank debt, that could make it easier for non-issuers to borrow locally. Furthermore, financial firms might use their new equity issuance proceeds in support of greater lending to local firms. These two influences could be particularly beneficial for small and medium-sized firms (de la Torre et al., 2010). More broadly, future work could examine the extent to which the selective reductions in the cost of equity either promote greater efficiency in the economy (i.e., by reducing financing constraints for relatively productive firms, and by providing indirect benefits for other firms), or result in inefficiencies by increasing the market power of a small number of large firms. 


\section{References}

Ahmed, S. and A. Zlate (2014). "Capital Flows to Emerging Market Economies: A Brave New World?" Journal of International Money and Finance 48 (B), 221-248.

Alfaro, L., A. Chanda, S. Kalemli-Ozcan, and S. Sayek (2004). "FDI and Economic Growth: The Role of Local Financial Markets." Journal of International Economics 64 (1), 89-112.

Alfaro, L., A. Chari, and F. Kanczuk (2017). "The Real Effects of Capital Controls: Firm-level Evidence from a Policy Experiment." Journal of International Economics 108, 191-210.

Asquith, P. and D. Mullins (1986). "Equity Issues and Offering Dilution." Journal of Financial Economics 15, 61-89.

Avdjiev, S., B. Hardy, S. Kalemli-Ozcan, and L. Serven (2018). "Gross Capital Inflows to Banks, Corporates, and Sovereigns.” NBER Working Paper No. 23116.

Baker, M. and J. Wurgler (2000). "The Equity Share in New Issues and Aggregate Stock Returns." Journal of Finance 55, 2219-2257.

Baskaya, Y., J. di Giovanni, S. Kalemli-Ozcan, and M. Ulu (2017a). "International Spillovers and Local Credit Cycles.” NBER Working Paper No. 23149.

Baskaya, Y., J. di Giovanni, S. Kalemli-Ozcan, J.L. Peydro, and M. Ulu (2017b). "Capital Flows and the International Credit Channel." Journal of International Economics 108 (Supplement 1), 15-22.

Bekaert, G., C. Harvey, and C. Lundblad (2005). "Does Financial Liberalization Spur Growth?” Journal of Financial Economics 77 (1), 3-55.

Benos, E. and Weisbach, M. (2004). "Private Benefits and Cross-listings in the United States." Emerging Markets Review 5 (2), 217-240.

Blanchard, O. (2019). "Relax. Don't Relax Too Much, But Relax.” Financial Times Alphachat.

Brown, J., S. Fazzari, and B. Petersen (2009). "Financing Innovation and Growth: Cash Flow, External Equity and the 1990s R\&D Boom." Journal of Finance 64 (1), 151-185.

Bruno, V. and H.S. Shin (2017). "Global Dollar Credit and Carry Trades: A Firm-level Analysis." Review of Financial Studies 30 (3), 703-749.

Caballero, J., U. Panizza, and A. Powell (2016). "The Second Wave of Global Liquidity: Why are Firms Acting Like Financial Intermediaries?” Inter-American Development Bank Working Paper No. 641,

Calomiris, C., M. Larrain, S. Schmukler, and T. Williams (2019). "Search for Yield in Large International Corporate Bonds: Investor Behavior and Firm Responses." NBER Working Paper No. 25979 and World Bank Policy Research Working Paper No. 8890.

Cameron, A.C. and D. Miller (2015). "A Practitioner's Guide to Cluster-Robust Inference." Journal of Human Resources 50, 317-372.

Cameron, A.C. and P. Trivedi (2009). "Microeconometrics Using Stata." Chapter 13 of Bootstrap Methods. Stata Press.

Cameron, A.C., J. Gelbach, and D. Miller (2006). "Robust Inference with Multi-way Clustering." NBER Technical Working Paper No. 327.

Chari, A. and P.B. Henry (2004). "Risk Sharing and Asset Prices: Evidence from A Natural Experiment.” Journal of Finance 59 (3), 1295-1324.

Chari, A. and P.B. Henry (2008). "Firm-specific Information and the Efficiency of Investment." Journal of Financial Economics 87 (3), 636-655.

Chari, A., K.S. Stedman, and C. Lundblad (2017) "Taper Tantrums: QE, Its Aftermath, and Emerging Market Capital Flows.” NBER Working Paper No. 23474. 
Chui, M., I. Fender, and V. Sushko (2014). "Risks Related to EME Corporate Balance Sheets: The Role of Leverage and Currency Mismatch.” BIS Quarterly Review September 2014, Bank for International Settlements.

Claessens, S. and S. Schmukler (2007). "International Financial Integration through Equity Markets: Which Firms from which Countries Go Global?” Journal of International Money and Finance 26 (5), 788-813.

Claessens, S., H. Tong, and S.-J. Wei (2012). "From the Financial Crisis to the Real Economy: Using Firm-level Data to Identify Transmission Channels." Journal of International Economics 88 (2), 375-387.

de la Torre, A., M.S. Martinez Peria, and S. Schmukler (2010). "Bank Involvement with SMEs: Beyond Relationship Lending." Journal of Banking and Finance 34 (9), 2280-2293.

Didier, T., R. Levine, and S. Schmukler (2015). "Capital Market Financing, Firm Growth, Firm Size Distribution.” NBER Working Paper No. 20336 and World Bank Policy Research Paper No. 7353.

Doidge, C. (2004). "U.S. Cross-listings and the Private Benefits of Control: Evidence from Dual-Class Firms." Journal of Financial Economics 72 (3), 519-553.

Doidge, C., A. Karolyi, K. Lins, D. Miller, and R. Stulz (2009). "Private Benefits of Control, Ownership, and the Cross-Listing Decision.” Journal of Finance 64 (1), 425-466.

Erel, I., B. Julio, W. Kim, and M. Weisbach, (2011). "Macroeconomic Conditions and Capital Raising." Review of Financial Studies 25 (2), 341-376.

Forbes, K. (2007). "One Cost of the Chilean Capital Controls: Increased Financial Constraints for Smaller Traded Firms." Journal of International Economics 71 (2), 294-323.

Forbes, K. and F. Warnock (2012). "Capital Flow Waves: Surges, Stops, Flight and Retrenchment.” Journal of International Economics 88 (2), 235-251.

Forbes, K., M. Fratzscher, T. Kostka, and R. Straub (2016). "Bubble thy Neighbour: Portfolio Effects and Externalities from Capital Controls." Journal of International Economics 99, 85-104.

Fratzscher, M. (2012). "Capital Flows, Push Versus Pull Factors and the Global Financial Crisis." Journal of International Economics 88 (2), 341-356.

Hau, H. and H. Rey (2006). "Exchange Rates, Equity Prices, and Capital Flows." Review of Financial Studies 19 (1), 273-317.

Henry, P. (2000a). "Do Stock Market Liberalizations Cause Investment Booms?” Journal of Financial Economics 58, 301-334.

Henry, P. (2000b). "Stock Market Liberalization, Economic Reform, and Emerging Market Equity Prices." Journal of Finance 55 (1-2), 529-564.

IMF (2010). "Capital Inflows: The Role of Controls." Staff Position Note. Prepared by J. Ostry, A. Ghosh, K. Habermeier, M. Chamon, M. Qureshi, and D. Reinhardt, International Monetary Fund.

Jansen, W.J. (2003). "What Do Capital Inflows Do? Dissecting the Transmission Mechanism for Thailand, 1980-1996." Journal of Macroeconomics 25 (4), 457-480.

Kaminsky, G. and C.M. Reinhart (1999). "The Twin Crises: The Causes of Banking and Balance of Payments Problems.” American Economic Review 89 (4), 473-500.

Karaca-Mandic, P. and K. Train (2003). "Standard Error Correction in Two-stage Estimation with Nested Samples." Econometrics Journal 6 (2), 401-407.

Karolyi, G.A. (2006). "The World of Cross-Listings and Cross-Listings of the World: Challenging Conventional Wisdom." Review of Finance 10 (1), 99-152.

Karolyi, G.A. (2015). Cracking the Emerging Markets Enigma. New York: Oxford University Press. 
Kim, S. and D.Y. Yang (2011). "The Impact of Capital Inflows on Asset Prices in Emerging Asian Economies: Is Too Much Money Chasing Too Little Good?” Open Economies Review 22 (2), 293-315.

Kim, W. and M. Weisbach (2008). "Motivations for Public Equity Offers." Journal of Financial Economics 87 (2), 281-307.

Kose, A., K. Rogoff, E. Prasad, and S.-J. Wei (2009). "Financial Globalization: A Reappraisal." IMF Staff Papers 16 (1), 8-62.

Kose, A., K. Rogoff, E. Prasad, and S.-J. Wei (2010). "Financial Globalization and Economic Policies." Handbook of Development Economics, Vol. 5, edited by D. Rodrik and M. Rosenzweig, North-Holland, 4283-4362.

Lane, P.R. and G.M. Milesi-Ferretti (2017). "International Financial Integration in the Aftermath of the Global Financial Crisis.” IMF Working Paper No. 17/115.

Mitton, T. (2006). "Stock Market Liberalization and Operating Performances at the Firm Level." Journal of Financial Economics 81 (3), 625-647.

Moreno, R. and J.M. Serena Garralda (2018). "Firms' Credit Risk and the Onshore Transmission of the Global Financial Cycle.” BIS Working Paper No. 712.

Oberholzer-Gee, F., and K. Strumpf (2007). "The Effect of File Sharing on Record Sales: An Empirical Analysis." Journal of Political Economy 115 (1), 1-42.

Olaberría, E. (2014). "Capital Inflows and Booms in Asset Prices: Evidence from a Panel of Countries." In Capital Mobility and Monetary Policy, M. Fuentes D., C. Raddatz, and C.M. Reinhart (Eds.), 1 (18), 255-290, Central Bank of Chile.

Pagano, M., A. Röell, and J. Zechner (2002). "The Geography of Equity Listing: Why Do Companies List Abroad?” Journal of Finance 57 (6), 2651-2694.

Pagano, M., F. Panetta, and L. Zingales (1998). "Why Do Companies Go Public?” Journal of Finance 53 (1), 27-64.

Petrin, A. and K. Train (2003). "Omitted Product Attributes in Discrete Choice Models." NBER Working Paper No. 9452.

Petrin, A. and K. Train (2010). "A Control Function Approach to Endogeneity in Consumer Choice Models." Journal of Marketing Research 47 (1), 3-13.

Powell, A. (2014). "Global Recovery and Monetary Normalization: Escaping a Chronicle Foretold?" Washington, DC: Inter-American Development Bank.

Raddatz, C., S. Schmukler, and T. Williams (2017). "International Asset Allocations and Capital flows: The Benchmark Effect." Journal of International Economics 108, 413-430.

Reinhart, C.M. and V.R. Reinhart (2009). "Capital Flow Bonanzas: An Encompassing View of the Past and Present." In NBER International Seminar on Macroeconomics 2008, 9-62, National Bureau of Economic Research.

Schmukler, S. and E. Vesperoni (2006). "Financial Globalization and Debt Maturity in Emerging Economies." Journal of Development Economics 79 (1), 183-207.

Stulz, R. (2005). “The Limits of Financial Globalization.” Journal of Finance 60 (4), 1595-1638.

Tillmann, P. (2013). "Capital Flows and Asset Prices: Evidence from Emerging Asia." Journal of Banking and Finance 37 (3), 717-729.

Tong, H. and S.-J. Wei (2010). "The Composition Matters: Capital Flows and Liquidity Constraint during a Global Economic Crisis." Review of Financial Studies 24 (6), 20232052. 
Figure 1

\section{Emerging Market Equity Issuances and Equity Capital Inflows}

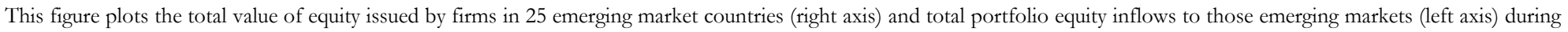
the 1991-2016 period. All values are reported in billions of 2011 U.S. dollars (USD).

200

300

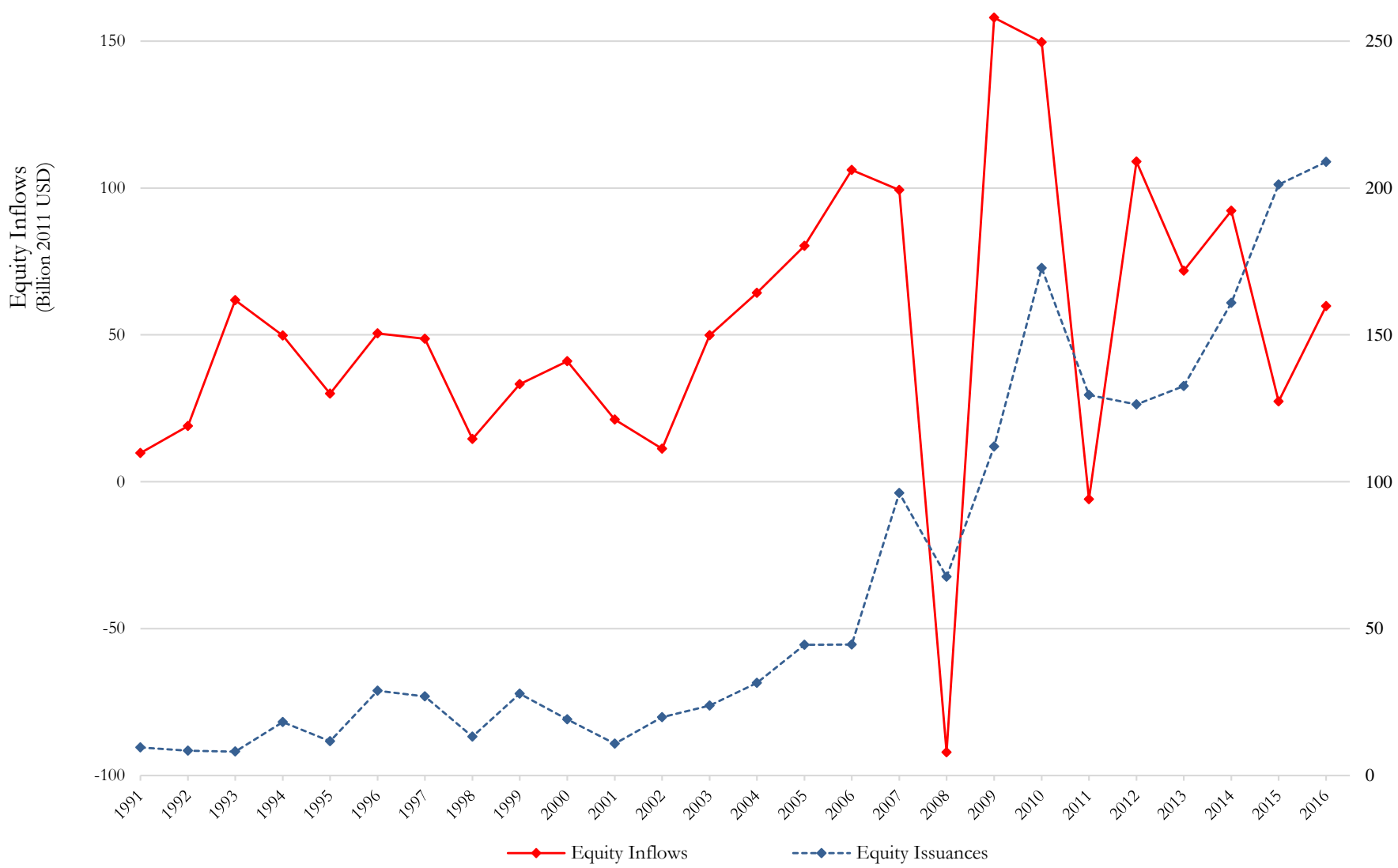


Figure 2

\section{Other Countries' Equity Value and Issuance Volume and Equity Capital Inflows for Mexico}

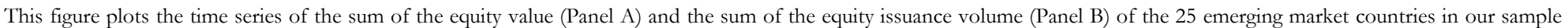

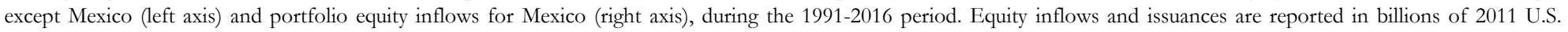
Dollars (USD).

Panel A. Other Countries' Equity Value and Equity Inflows for Mexico

16,000

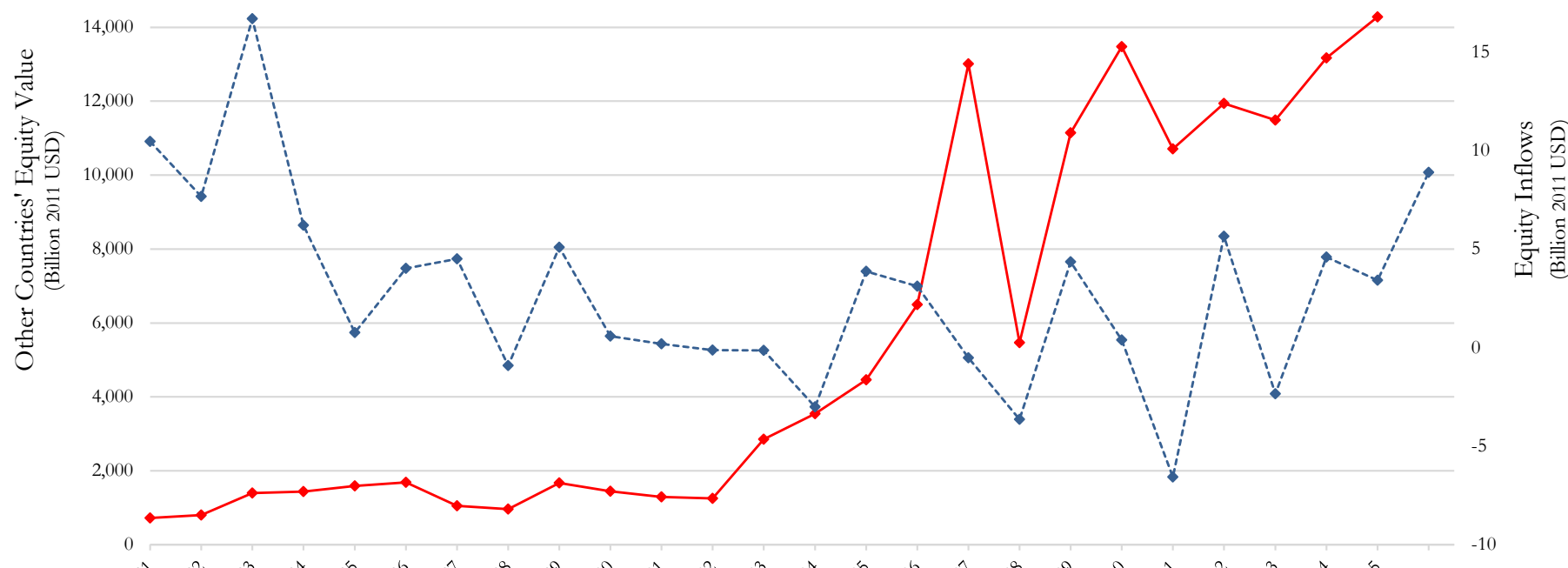

$\longrightarrow$ Other Countries' Equity Value $\quad$--- --- Equity Inflows

Panel B. Other Countries' Equity Issuance Volume and Equity Inflows for Mexico

350

20

范

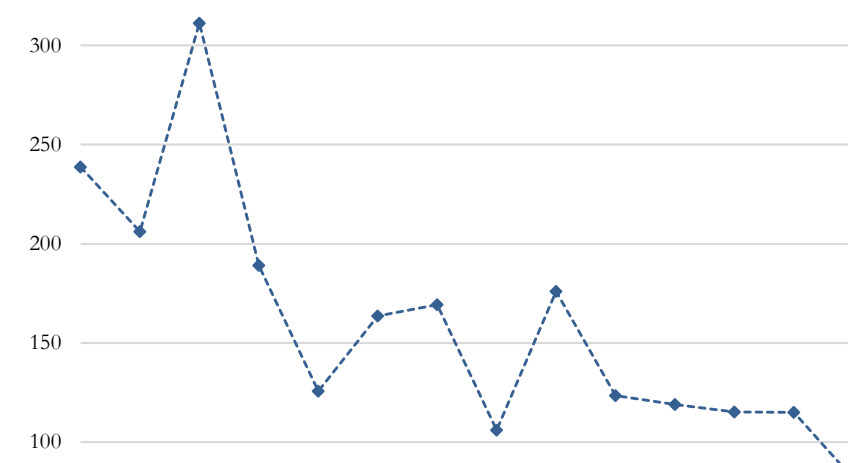

50
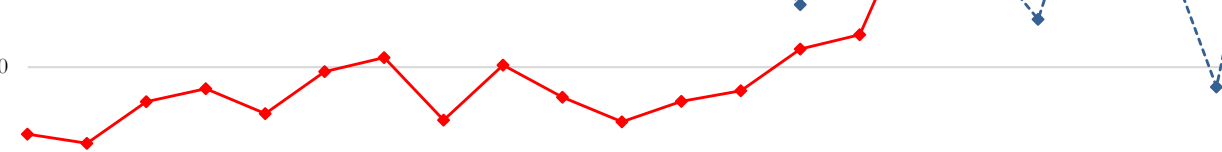

15

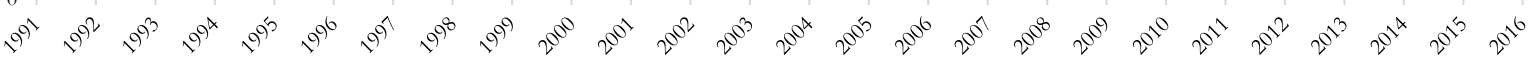

$-10$ 
Figure 3

Emerging Market Equity Issuances and Equity Capital Inflows, Scaled by GDP

This figure plots the average value of equity issued by firms in 25 emerging market countries over GDP (right axis) and the average value of portfolio equity inflows to those emerging markets over GDP (left axis) during the 1991-2016 period. Both equity issuance and inflows are scaled by each country's GDP and then averaged across countries.

$1.20 \%$

$0.90 \%$

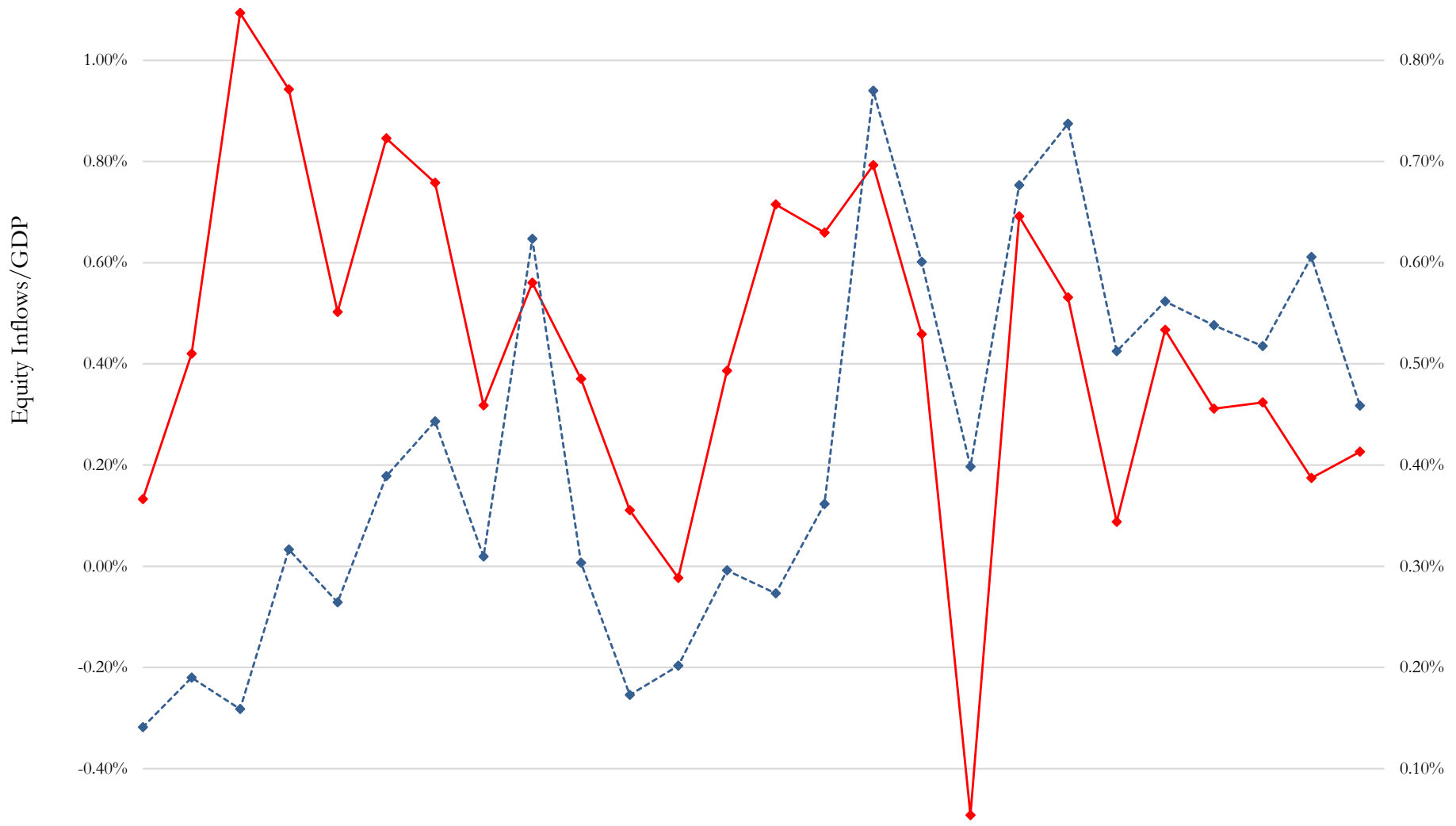

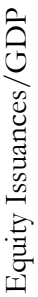

$-0.60 \%$
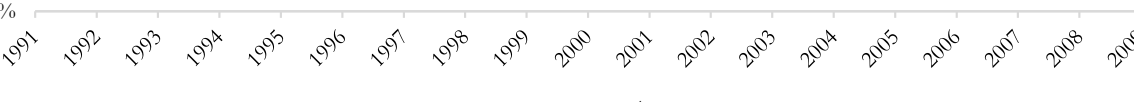

$0.00 \%$

Equity Inflows/GDP

---ه--- Equity Issuances/GDP 


\section{Table 1}

\section{Summary Statistics of Number of Firms and Equity Issuance Activity}

This table reports summary statistics of firms' equity issuance activity for each of the 25 emerging market countries in our sample during the 1991-2016 period. All issuance values are in millions of 2011 U.S. dollars (USD).

\begin{tabular}{|c|c|c|c|}
\hline Country & $\begin{array}{c}\text { Number } \\
\text { of } \\
\text { Firms }\end{array}$ & $\begin{array}{l}\text { Average Annual } \\
\text { Issuance } \\
\text { Value } \\
\text { (Million USD) }\end{array}$ & $\begin{array}{l}\text { Average Annual } \\
\text { Issuance Value } \\
\text { / Number of Firms } \\
\text { (Million USD) }\end{array}$ \\
\hline & (1) & (2) & (3) \\
\hline Argentina & 85 & 626 & 7 \\
\hline Brazil & 323 & 5,572 & 17 \\
\hline Chile & 152 & 1,156 & 8 \\
\hline China & 3,660 & 24,863 & 7 \\
\hline Colombia & 33 & 524 & 16 \\
\hline Czech Republic & 7 & 66 & 9 \\
\hline Egypt, Arab Rep. & 140 & 461 & 3 \\
\hline Hungary & 21 & 93 & 4 \\
\hline India & 2,105 & 6,388 & 3 \\
\hline Indonesia & 499 & 3,280 & 7 \\
\hline Israel & 226 & 1,009 & 4 \\
\hline Jordan & 127 & 149 & 1 \\
\hline Korea, Rep. & 1,136 & 6,851 & 4 \\
\hline Malaysia & 146 & 2,687 & 2 \\
\hline Mexico & 52 & 1,522 & 10 \\
\hline Morocco & 129 & 96 & 2 \\
\hline Pakistan & 48 & 100 & 1 \\
\hline Peru & 231 & 105 & 2 \\
\hline Philippines & 423 & 1,519 & 7 \\
\hline Poland & 196 & 1,139 & 3 \\
\hline Russian Federation & 231 & 3,745 & 19 \\
\hline South Africa & 1,825 & 2,310 & 10 \\
\hline Thailand & 651 & 2,162 & 3 \\
\hline Turkey & 237 & 966 & 4 \\
\hline Venezuela, R.B. & 40 & 104 & 3 \\
\hline $\begin{array}{l}\text { Total (Column 1) and } \\
\text { Average (Columns } 2 \text { and 3) }\end{array}$ & 12,723 & 2,700 & 6 \\
\hline
\end{tabular}




\section{Table 2}

\section{Equity Inflows and Equity Issuance Activity: Aggregate Evidence}

This table reports country-level panel OLS regressions of aggregate equity issuance on equity inflows for 25 emerging market countries during the 1991-2016 period. Column (1) reports the regression for the log of one plus aggregate equity issuance on the $\log$ of portfolio equity inflows. Column (2) reports the regression for aggregate equity issuance/GDP on equity inflows/GDP. Columns (3) and (4) report the regressions for aggregate equity issuance/GDP on equity inflows/GDP, restricting the sample to observations with positive and negative inflows, respectively. All variables are winsorized at the $1 \%$ level. All regressions include country and year fixed effects. Standard errors are double clustered at the country and year levels. $*, * *$, and $* * *$ indicate statistical significance at the $10 \%, 5 \%$, and $1 \%$ levels, respectively.

\begin{tabular}{|c|c|c|c|c|}
\hline & $\begin{array}{l}\log (1+\text { Equity } \\
\text { Issuance })\end{array}$ & $\begin{array}{c}\text { Equity } \\
\text { Issuance / GDP }\end{array}$ & $\begin{array}{c}\text { Equity } \\
\text { Issuance / GDP } \\
(\text { Inflows }>0)\end{array}$ & $\begin{array}{c}\text { Equity } \\
\text { Issuance / GDP } \\
\text { (Inflows < 0) }\end{array}$ \\
\hline & (1) & (2) & (3) & (4) \\
\hline Log(Equity Inflows) & $\begin{array}{l}0.5240 * * * \\
(0.093)\end{array}$ & & & \\
\hline Equity Inflows / GDP & & $\begin{array}{l}0.0652 * * \\
(0.029)\end{array}$ & $\begin{array}{l}0.1527 \text { *** } \\
(0.046)\end{array}$ & $\begin{array}{l}0.0260 \\
(0.037)\end{array}$ \\
\hline Country FE & Yes & Yes & Yes & Yes \\
\hline Year FE & Yes & Yes & Yes & Yes \\
\hline Number of Observations & 428 & 581 & 427 & 154 \\
\hline
\end{tabular}


Table 3

\section{Equity Inflows and Firms' Equity Issuance Activity}

This table reports firm-level panel OLS regressions of the log of one plus equity issuance on the log of portfolio equity inflows and its interaction with the large firm dummy variable for 25 emerging market countries during the 1991-2016 period. A firm is classified as large if its prior period's market value of equity is in the top decile of the market value distribution within a country and year. Columns (1)-(3) and (4)-(5) report the analysis for contemporaneous and lagged equity inflows, respectively. All variables are winsorized at the $1 \%$ level. Regressions in columns (1), (2), and (4) include firm and year fixed effects. Regressions in columns (3) and (5) include firm and countryyear fixed effects. Standard errors are double clustered at the country and year levels. ${ }^{*},{ }^{*}$, and $* * *$ indicate statistical significance at the $10 \%, 5 \%$, and $1 \%$ levels, respectively.

\begin{tabular}{|c|c|c|c|c|c|}
\hline & \multicolumn{5}{|c|}{ Log(1+Equity Issuance) } \\
\hline & $(1)$ & $(2)$ & (3) & (4) & (5) \\
\hline Log(Equity Inflows) & $\begin{array}{l}0.0395 * \\
(0.022)\end{array}$ & $\begin{array}{l}0.0360 \\
(0.022)\end{array}$ & & & \\
\hline $\log ($ Equity Inflows $) *$ Large Firm & & $\begin{array}{l}0.0223 * * * \\
(0.002)\end{array}$ & $\begin{array}{l}0.0210^{* * *} \\
(0.001)\end{array}$ & & \\
\hline Log(Lagged Equity Inflows) & & & & $\begin{array}{l}0.0260 \\
(0.025)\end{array}$ & \\
\hline Log(Lagged Equity Inflows $) *$ Large Firm & & & & $\begin{array}{l}0.0183^{* * *} \\
(0.003)\end{array}$ & $\begin{array}{l}0.0173 \text { *** } \\
(0.003)\end{array}$ \\
\hline Firm FE & Yes & Yes & Yes & Yes & Yes \\
\hline Year FE & Yes & Yes & No & Yes & No \\
\hline Country-Year FE & No & No & Yes & No & Yes \\
\hline Number of Observations & 88,314 & 88,314 & 88,314 & 88,112 & 88,112 \\
\hline
\end{tabular}




\section{Table 4}

\section{Equity Inflows and Firms' Equity Issuance Activity Effects for Firms of Different Sizes}

This table reports firm-level panel OLS regressions of the log of one plus equity issuance on the log of contemporaneous or lagged portfolio equity inflows and its interaction with the large firm dummy variable in Panels A and B, respectively, for 25 emerging market countries during the 1991-2016 period. A firm is classified as large if its prior period's market value of equity is in the top 10th (column 1), 20th (column 2), 30th (column 3), 40th (column 4), or 50th (column 5) percentile of the market value distribution within a country and year. All variables are winsorized at the $1 \%$ level. All regressions include firm and country-year fixed effects. Standard errors are double clustered at the country and year levels. *, **, and *** indicate statistical significance at the $10 \%, 5 \%$, and $1 \%$ levels, respectively.

\begin{tabular}{|c|c|c|c|c|c|}
\hline \multicolumn{6}{|c|}{ Panel A. Contemporaneous Inflows } \\
\hline & \multicolumn{5}{|c|}{ Log(1+Equity Issuance) } \\
\hline & Top 10 & Top 20 & Top 30 & Top 40 & Top 50 \\
\hline & $(1)$ & $(2)$ & (3) & (4) & (5) \\
\hline Log(Equity Inflows) $*$ Large Firm & $\begin{array}{l}0.0210 * * * \\
(0.001)\end{array}$ & $\begin{array}{l}0.0175 \text { *** } \\
(0.004)\end{array}$ & $\begin{array}{l}0.0133 \text { ** } \\
(0.006)\end{array}$ & $\begin{array}{l}0.0124^{* *} \\
(0.005)\end{array}$ & $\begin{array}{l}0.0095 * * \\
(0.004)\end{array}$ \\
\hline Firm FE & Yes & Yes & Yes & Yes & Yes \\
\hline Country-Year FE & Yes & Yes & Yes & Yes & Yes \\
\hline Number of Observations & 88,314 & 88,314 & 88,314 & 88,314 & 88,314 \\
\hline \multicolumn{6}{|c|}{ Panel B. Lagged Inflows } \\
\hline & \multicolumn{5}{|c|}{$\log (1+$ Equity Issuance $)$} \\
\hline & Top 10 & Top 20 & Top 30 & Top 40 & Top 50 \\
\hline & $(1)$ & $(2)$ & (3) & (4) & (5) \\
\hline Log(Lagged Equity Inflows) * Large Firm & $\begin{array}{l}0.0173 \text { *** } \\
(0.003)\end{array}$ & $\begin{array}{l}0.0139 \text { ** } \\
(0.005)\end{array}$ & $\begin{array}{l}0.0115 * \\
(0.007)\end{array}$ & $\begin{array}{l}0.0112 \text { ** } \\
(0.005)\end{array}$ & $\begin{array}{l}0.0084 \\
(0.005)\end{array}$ \\
\hline Firm FE & Yes & Yes & Yes & Yes & Yes \\
\hline Country-Year FE & Yes & Yes & Yes & Yes & Yes \\
\hline Number of Observations & 88,112 & 88,112 & 88,112 & 88,112 & 88,112 \\
\hline
\end{tabular}




\section{Table 5}

\section{Equity Inflows and Firms' Equity Issuance Activity Instrument: Other Countries' Orthogonalized Equity Value}

This table reports the first- and second-stage regressions for the instrumental variable approach, using other countries' orthogonalized equity value as instrument, for 25 emerging market countries during the 1991-2016 period. We compute the orthogonalized equity value for each country as the residual of a time-series regression of the log of market value of emerging markets on the $\log$ of own-country market value. In Panel A, column (1) reports country-level panel OLS regressions of the log of portfolio equity inflows on other countries' orthogonalized equity value. Column (2) reports firm-level panel second-stage regressions of the log of one plus equity issuance on the interaction of the log of portfolio equity inflows with the large firm dummy (top decile of the prior period's equity market value distribution within a country and year). Panel B reports the same regressions using lagged portfolio equity inflows and the one-year lag of other countries' orthogonalized equity value. Regressions in column (1) include country and year fixed effects. Regressions in column (2) include firm and country-year fixed effects. All variables are winsorized at the $1 \%$ level. First-stage standard errors are double clustered at the country and year levels. Second-stage standard errors are block bootstrapped with 1,000 repetitions, double clustering at the country and year levels. ${ }^{*}, * *$, and $* * *$ indicate statistical significance at the $10 \%, 5 \%$, and $1 \%$ levels, respectively.

\begin{tabular}{|c|c|c|}
\hline \multicolumn{3}{|c|}{ Panel A. Contemporaneous Inflows } \\
\hline & First Stage & Second Stage \\
\hline & $\begin{array}{l}\log (\text { Equity } \\
\text { Inflows) }\end{array}$ & $\begin{array}{c}\log (1+\text { Equity } \\
\text { Issuance })\end{array}$ \\
\hline & $(1)$ & $(2)$ \\
\hline Other Countries' Orthogonalized Equity Value & $\begin{array}{l}-0.5654 \text { *** } \\
(0.165)\end{array}$ & \\
\hline Log(Equity Inflows) $*$ Large Firm & & $\begin{array}{l}0.0204 \text { *** } \\
(0.004)\end{array}$ \\
\hline Firm FE & No & Yes \\
\hline Country FE & Yes & No \\
\hline Year FE & Yes & No \\
\hline Country-Year & No & Yes \\
\hline Number of Observations & 329 & 84,963 \\
\hline Kleibergen-Paap Wald F-Stat & 11.70 &.. \\
\hline \multicolumn{3}{|c|}{ Panel B. Lagged Inflows } \\
\hline & First Stage & Second Stage \\
\hline & $\begin{array}{c}\text { Log(Lagged } \\
\text { Equity Inflows) } \\
\end{array}$ & $\begin{array}{c}\log (1+\text { Equity } \\
\text { Issuance })\end{array}$ \\
\hline & $(1)$ & $(2)$ \\
\hline Lagged Other Countries' Orthogonalized Equity Value & $\begin{array}{l}-0.6199 \text { *** } \\
(0.172)\end{array}$ & \\
\hline Log(Lagged Equity Inflows) $*$ Large Firm & & $\begin{array}{l}0.0174 \text { *** } \\
(0.005)\end{array}$ \\
\hline Firm FE & No & Yes \\
\hline Country FE & Yes & No \\
\hline Year FE & Yes & No \\
\hline Country-Year & No & Yes \\
\hline Number of Observations & 315 & 83,160 \\
\hline Kleibergen-Paap Wald F-Stat & 12.98 &.. \\
\hline
\end{tabular}




\section{Table 6}

\section{Equity Inflows and Firms' Equity Issuance Activity Instrument: Other Countries' Orthogonalized Equity Issuance Volume}

This table reports the first- and second-stage regressions for the instrumental variable approach, using other countries' orthogonalized equity issuance volume as instrument, for 25 emerging market countries during the 1991-2016 period. We compute the orthogonalized equity issuance for each country as the residual of a timeseries regression of the log of equity issuance volume of emerging markets on the log of one plus own-country issuance. In Panel A, column (1) reports country-level panel OLS regressions of the log of portfolio equity inflows on other countries' orthogonalized equity issuance. Column (2) reports firm-level panel second-stage regressions of the $\log$ of one plus equity issuance on the interaction of the $\log$ of portfolio equity inflows with the large firm dummy (top decile of the prior period's equity market value distribution within a country and year). Panel B reports the same regressions using lagged portfolio equity inflows and the one-year lag of other countries' orthogonalized equity issuance. Regressions in column (1) include country and year fixed effects. Regressions in column (2) include firm and country-year fixed effects. All variables are winsorized at the 1\% level. First-stage standard errors are double clustered at the country and year levels. Second-stage standard errors are block bootstrapped with 1,000 repetitions, double clustering at the country and year levels. ${ }^{*}, *$, and *** indicate statistical significance at the $10 \%, 5 \%$, and $1 \%$ levels, respectively.

\begin{tabular}{lcc}
\hline & Panel A. Contemporaneous Inflows & \\
\hline & First Stage & Second Stage \\
& $\begin{array}{c}\text { Log(Equity } \\
\text { Inflows })\end{array}$ & $\begin{array}{c}\text { Log(1+Equity } \\
\text { Issuance) }\end{array}$ \\
\cline { 2 - 3 } & $(1)$ & $(2)$ \\
\hline Other Countries' Orthogonalized Equity Issuance Volume & $-0.7548 * * *$ & \\
& $(0.187)$ & \\
Log(Equity Inflows) * Large Firm & & \\
& & $0.0215 * * *$ \\
Firm FE & & $(0.003)$ \\
Country FE & No & \\
Year FE & Yes & Yes \\
Country-Year & Yes & No \\
Number of Observations & No & Yes \\
Kleibergen-Paap Wald F-Stat & 428 & 88,314 \\
\hline
\end{tabular}

\begin{tabular}{|c|c|c|}
\hline \multicolumn{3}{|l|}{ Panel B. Lagged Inflows } \\
\hline & First Stage & Second Stage \\
\hline & $\begin{array}{l}\text { Log(Lagged } \\
\text { Equity Inflows) }\end{array}$ & $\log (1+$ Equity \\
\hline & $(1)$ & $(2)$ \\
\hline Lagged Other Countries' Orthogonalized Equity Issuance Volume & $\begin{array}{l}-0.7976 \text { *** } \\
(0.192)\end{array}$ & \\
\hline Log(Lagged Equity Inflows) * Large Firm & & $\begin{array}{l}0.0180 \text { *** } \\
(0.004)\end{array}$ \\
\hline Firm FE & No & Yes \\
\hline Country FE & Yes & No \\
\hline Year FE & Yes & No \\
\hline Country-Year & No & Yes \\
\hline Number of Observations & 413 & 88,112 \\
\hline Kleibergen-Paap Wald F-Stat & 17.25 &.. \\
\hline
\end{tabular}


Table 7

\section{Equity Inflows and Firms' Equity Issuance Activity, Adding First-Stage Controls Instrument: Other Countries' Orthogonalized Equity Value}

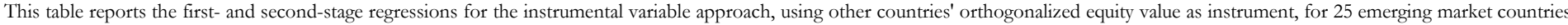

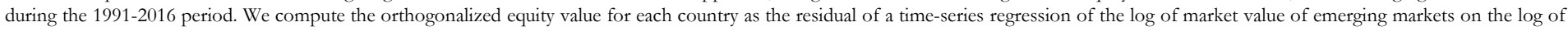

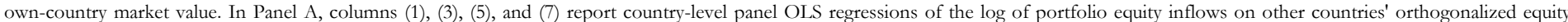

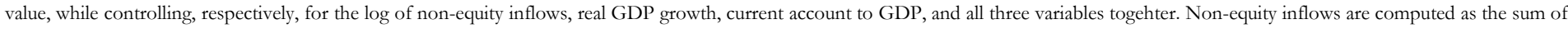

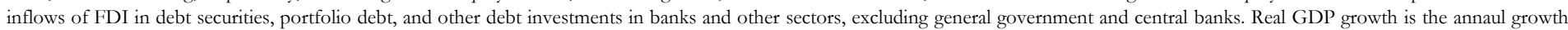

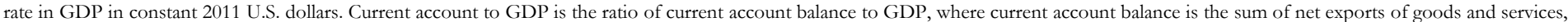

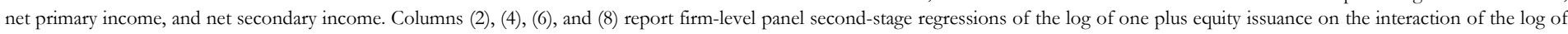

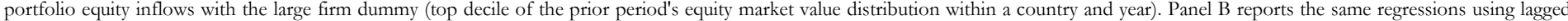

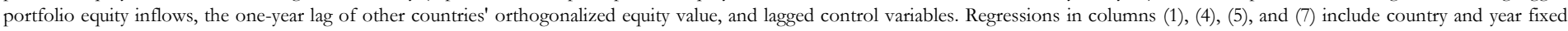

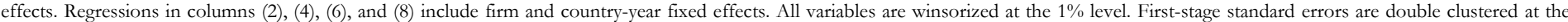

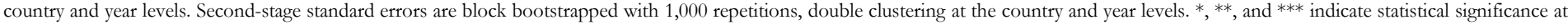
the $10 \%, 5 \%$, and $1 \%$ levels, respectively.

\begin{tabular}{|c|c|c|c|c|c|c|c|c|}
\hline \multicolumn{9}{|c|}{ Panel A. Contemporaneous Inflows } \\
\hline & First Stage & Second Stage & First Stage & Second Stage & First Stage & Second Stage & First Stage & Second Stage \\
\hline & $\begin{array}{l}\text { Log(Equity } \\
\text { Inflows) }\end{array}$ & $\begin{array}{c}\log (1+ \\
\text { Equity } \\
\text { Issuance) }\end{array}$ & $\begin{array}{c}\log (\text { Equity } \\
\text { Inflows) }\end{array}$ & $\begin{array}{c}\log (1+ \\
\text { Equity } \\
\text { Issuance) }\end{array}$ & $\begin{array}{l}\log (\text { Equity } \\
\text { Inflows) }\end{array}$ & $\begin{array}{c}\log (1+ \\
\text { Equity } \\
\text { Issuance) }\end{array}$ & $\begin{array}{l}\text { Log(Equity } \\
\text { Inflows) }\end{array}$ & $\begin{array}{c}\log (1+ \\
\text { Equity } \\
\text { Issuance) }\end{array}$ \\
\hline & $(1)$ & $(2)$ & (3) & (4) & (5) & $(6)$ & $(7)$ & $(8)$ \\
\hline Other Countries' Orthogonalized Equity Value & $\begin{array}{l}-0.5369 \text { *** } \\
(0.163)\end{array}$ & & $\begin{array}{l}-0.6052 \text { *** } \\
(0.173)\end{array}$ & & $\begin{array}{l}-0.4799 \text { ** } \\
(0.195)\end{array}$ & & $\begin{array}{c}-0.4842 \text { ** } \\
(0.192)\end{array}$ & \\
\hline Log(Equity Inflows) & & $\begin{array}{l}0.0204 \text { *** } \\
(0.003)\end{array}$ & & $\begin{array}{l}0.0203 \text { *** } \\
(0.004)\end{array}$ & & $\begin{array}{l}0.0203 * * * \\
(0.003)\end{array}$ & & $\begin{array}{l}0.0202 \text { *** } \\
(0.003)\end{array}$ \\
\hline Log(Non-Equity Inflows) & $\begin{array}{l}0.1826 * \\
(0.089)\end{array}$ & & & & & & $\begin{array}{l}0.1573 * * \\
(0.075)\end{array}$ & \\
\hline Real GDP Growth & & & $\begin{array}{r}-0.8388 \\
(0.718)\end{array}$ & & & & $\begin{array}{r}-0.2849 \\
(0.998)\end{array}$ & \\
\hline Current Account to GDP & & & & & $\begin{array}{r}-0.0391 \\
(0.034)\end{array}$ & & $\begin{array}{r}-0.0510 \\
(0.037)\end{array}$ & \\
\hline Firm FE & No & Yes & No & Yes & No & Yes & No & Yes \\
\hline Country FE & Yes & No & Yes & No & Yes & No & Yes & No \\
\hline Year FE & Yes & No & Yes & No & Yes & No & Yes & No \\
\hline Country-Year & No & Yes & No & Yes & No & Yes & No & Yes \\
\hline Number of Observations & 262 & 71,653 & 329 & 84,963 & 329 & 84,963 & 262 & 71,653 \\
\hline Kleibergen-Paap Wald F-Stat & 8.34 & .. & 6.21 & .. & 5.80 & .. & 6.23 & .. \\
\hline \multicolumn{9}{|c|}{ Panel B. Lagged Inflows } \\
\hline & First Stage & Second Stage & First Stage & Second Stage & First Stage & Second Stage & First Stage & Second Stage \\
\hline & $\begin{array}{c}\text { Log(Lagged } \\
\text { Equity } \\
\text { Inflows) }\end{array}$ & $\begin{array}{c}\log (1+ \\
\text { Equity } \\
\text { Issuance) }\end{array}$ & $\begin{array}{c}\text { Log(Lagged } \\
\text { Equity } \\
\text { Inflows })\end{array}$ & $\begin{array}{c}\log (1+ \\
\text { Equity } \\
\text { Issuance) }\end{array}$ & $\begin{array}{c}\text { Log(Lagged } \\
\text { Equity } \\
\text { Inflows) }\end{array}$ & $\begin{array}{c}\log (1+ \\
\text { Equity } \\
\text { Issuance) }\end{array}$ & $\begin{array}{c}\text { Log(Lagged } \\
\text { Equity } \\
\text { Inflows) }\end{array}$ & $\begin{array}{c}\log (1+ \\
\text { Equity } \\
\text { Issuance })\end{array}$ \\
\hline & $(1)$ & $(2)$ & (3) & (4) & (5) & (6) & $(7)$ & (8) \\
\hline Lagged Other Countries' Orthogonalized Equity Value & $\begin{array}{l}-0.5852 \text { *** } \\
(0.168)\end{array}$ & & $\begin{array}{l}-0.6561 * * * \\
(0.180)\end{array}$ & & $\begin{array}{c}-0.5308^{* *} \\
(0.202)\end{array}$ & & $\begin{array}{l}-0.5284 \text { ** } \\
(0.194)\end{array}$ & \\
\hline Log(Lagged Equity Inflows) & & $\begin{array}{l}0.0206 * * * \\
(0.005)\end{array}$ & & $\begin{array}{l}0.0175 * * * \\
(0.005)\end{array}$ & & $\begin{array}{l}0.0173 * * * \\
(0.005)\end{array}$ & & $\begin{array}{l}0.0204 \text { *** } \\
(0.004)\end{array}$ \\
\hline Log(Lagged Non-Equity Inflows) & $\begin{array}{l}0.1769 * \\
(0.097)\end{array}$ & & & & & & $\begin{array}{l}0.1502 * \\
(0.083)\end{array}$ & \\
\hline Lagged Real GDP Growth & & & $\begin{array}{r}-0.7653 \\
(0.712)\end{array}$ & & & & $\begin{array}{r}-0.1920 \\
(0.998)\end{array}$ & \\
\hline Lagged Current Account to GDP & & & & & $\begin{array}{r}-0.0385 \\
(0.035)\end{array}$ & & $\begin{array}{r}-0.0529 \\
(0.038)\end{array}$ & \\
\hline Firm FE & No & Yes & No & Yes & No & Yes & No & Yes \\
\hline Country FE & Yes & No & Yes & No & Yes & No & Yes & No \\
\hline Year FE & Yes & No & Yes & No & Yes & No & Yes & No \\
\hline Country-Year & No & Yes & No & Yes & No & Yes & No & Yes \\
\hline Number of Observations & 251 & 71,267 & 315 & 83,160 & 315 & 83,160 & 251 & 71,267 \\
\hline Kleibergen-Paap Wald F-Stat & 8.98 & .. & 6.77 & .. & 6.10 & .. & 6.16 & .. \\
\hline
\end{tabular}


Table 8

\section{Equity Inflows, Bond Inflows and Firms' Equity and Bond Issuance Activity Instrument: Other Countries' Orthogonalized Equity Value}

This table reports the first- and second-stage regressions for the instrumental variable approach, using other countries' orthogonalized equity value as instrument, for 25 emerging market countries during the 1991-2016 period. We compute the orthogonalized equity value for each country as the residual of a time-series regression of the log of market value of emerging markets on the log of own-country market value. In Panel A, columns (1) and (3) report country-level panel OLS regressions of the log of portfolio debt inflows on other countries' orthogonalized equity value, while column (5) reports country-level panel OLS regressions of the log of portfolio equity inflows on other countries' orthogonalized equity value. Column (2) reports firm-level panel second-stage regressions of the log of one plus bond issuance on the interaction of the log of portfolio debt inflows with the large firm dummy (top decile of the prior period's equity market value distribution within a country and year). Column (4) reports firm-level panel second-stage regressions of the log of one plus equity issuance on the interaction of the log of portfolio debt inflows with the large firm dummy. Column (6) reports firm-level panel second-stage regressions of the log of one plus bond issuance on the interaction of the log of portfolio equity inflows with the large firm dummy. Panel B reports the same regressions using lagged portfolio equity and debt inflows and the one-year lag of other countries' orthogonalized equity value. Regressions in columns (1), (3), and (5) include country and year fixed effects. Regressions in columns (2), (4), and (6) include firm and country-year fixed effects. All variables are winsorized at the 1\% level. First-stage standard errors are double clustered at the country and year levels. Second-stage standard errors are block bootstrapped with 1,000 repetitions, double clustering at the country and year levels. *,**, and *** indicate statistical significance at the $10 \%$, $5 \%$, and $1 \%$ levels, respectively.

\begin{tabular}{|c|c|c|c|c|c|c|}
\hline \multicolumn{7}{|c|}{ Panel A. Contemporaneous Inflows } \\
\hline & First Stage & Second Stage & First Stage & Second Stage & First Stage & Second Stage \\
\hline & $\begin{array}{l}\log \text { (Bond } \\
\text { Inflows) }\end{array}$ & $\begin{array}{c}\log (1+ \\
\text { Bond } \\
\text { Issuance })\end{array}$ & $\begin{array}{l}\text { Log(Bond } \\
\text { Inflows) }\end{array}$ & $\begin{array}{c}\log (1+ \\
\text { Equity } \\
\text { Issuance) }\end{array}$ & $\begin{array}{l}\log (\text { Equity } \\
\text { Inflows) }\end{array}$ & $\begin{array}{c}\log (1+ \\
\text { Bond } \\
\text { Issuance })\end{array}$ \\
\hline & $(1)$ & $(2)$ & (3) & $(4)$ & (5) & $(6)$ \\
\hline Other Countries' Orthogonalized Equity Value & $\begin{array}{c}-1.3308 \text { *** } \\
(0.365)\end{array}$ & & $\begin{array}{c}-1.3308 \text { *** } \\
(0.365)\end{array}$ & & $\begin{array}{c}-0.5654 \text { *** } \\
(0.166)\end{array}$ & \\
\hline Log(Bond Inflows) * Large Firm & & $\begin{array}{l}0.0313 * * \\
(0.016)\end{array}$ & & $\begin{array}{r}-0.0017 \\
(0.008)\end{array}$ & & \\
\hline Log(Equity Inflows) $*$ Large Firm & & & & & & $\begin{array}{l}0.0437 * * * \\
(0.010)\end{array}$ \\
\hline Firm FE & No & Yes & No & Yes & No & Yes \\
\hline Country FE & Yes & No & Yes & No & Yes & No \\
\hline Year FE & Yes & No & Yes & No & Yes & No \\
\hline Country-Year & No & Yes & No & Yes & No & Yes \\
\hline Number of Observations & 231 & 18,315 & 231 & 44,325 & 329 & 33,921 \\
\hline Kleibergen-Paap Wald F-Stat & 13.27 & .. & 13.27 &.. & 11.66 &.. \\
\hline \multicolumn{7}{|c|}{ Panel B. Lagged Inflows } \\
\hline & First Stage & Second Stage & First Stage & Second Stage & First Stage & Second Stage \\
\hline & $\begin{array}{c}\text { Log(Lagged } \\
\text { Bond } \\
\text { Inflows) }\end{array}$ & $\begin{array}{c}\log (1+ \\
\text { Bond } \\
\text { Issuance })\end{array}$ & $\begin{array}{c}\text { Log(Lagged } \\
\text { Bond } \\
\text { Inflows) }\end{array}$ & $\begin{array}{c}\log (1+ \\
\text { Equity } \\
\text { Issuance) }\end{array}$ & $\begin{array}{c}\text { Log(Lagged } \\
\text { Equity } \\
\text { Inflows) }\end{array}$ & $\begin{array}{c}\log (1+ \\
\text { Bond } \\
\text { Issuance })\end{array}$ \\
\hline & $(1)$ & $(2)$ & (3) & (4) & $(5)$ & $(6)$ \\
\hline Lagged Other Countries' Orthogonalized Equity Value & $\begin{array}{c}-1.4070 \text { *** } \\
(0.368)\end{array}$ & & $\begin{array}{c}-1.4070 \text { *** } \\
(0.368)\end{array}$ & & $\begin{array}{c}-0.6199 \text { *** } \\
(0.173)\end{array}$ & \\
\hline Log(Lagged Bond Inflows $) *$ Large Firm & & $\begin{array}{l}0.0479 \text { *** } \\
(0.016)\end{array}$ & & $\begin{array}{r}-0.0049 \\
(0.008)\end{array}$ & & \\
\hline Log(Lagged Equity Inflows $) *$ Large Firm & & & & & & $\begin{array}{l}0.0480 \text { *** } \\
(0.014)\end{array}$ \\
\hline Firm FE & No & Yes & No & Yes & No & Yes \\
\hline Country FE & Yes & No & Yes & No & Yes & No \\
\hline Year FE & Yes & No & Yes & No & Yes & No \\
\hline Country-Year & No & Yes & No & Yes & No & Yes \\
\hline Number of Observations & 225 & 18,443 & 225 & 45,164 & 315 & 33,142 \\
\hline Kleibergen-Paap Wald F-Stat & 14.59 & .. & 14.59 & .. & 12.94 & .. \\
\hline
\end{tabular}




\section{Table 9 \\ Real Economic Effects of Equity Inflows Instrument: Other Countries' Orthogonalized Equity Value}

This table reports the second stage of firm-level panel instrumental variable regressions of the log of one plus firm real and financial outcomes on the interaction of the log of contemporaneous (Panel A) and lagged (Panel B) portfolio equity inflows with the large firm dummy (top decile of the prior period's equity market value distribution within a country and year) for 25 emerging market countries during the 1991-2016 period. We use the contemporaneous and lagged values of other countries' orthogonalized equity value as instruments for the contemporaneous and lagged portfolio equity inflows, respectively. We compute the orthogonalized equity value for each country as the residual of a time-series regression of the log of market value of emerging markets on the log of own-country market value. The dependent variables are capital expenditures, acquisitions, research and development expenditures, inventory accumulation, cash and short-term investments accumulation, and reduction of long-term debt. All variables are winsorized at the $1 \%$ level. Standard errors are block bootstrapped with 1,000 repetitions, double clustering at the country and year levels. All Regressions include firm and country-year fixed effects. *,**, and *** indicate statistical significance at the $10 \%, 5 \%$, and $1 \%$ levels, respectively.

\begin{tabular}{|c|c|c|c|c|c|c|}
\hline \multicolumn{7}{|c|}{ Panel A. Contemporaneous Inflows } \\
\hline & $\begin{array}{c}\log (1+ \\
\text { CAPEX })\end{array}$ & $\begin{array}{c}\log (1+ \\
\text { Acquisitions) }\end{array}$ & $\begin{array}{c}\log (1+ \\
\mathrm{R} \& \mathrm{D})\end{array}$ & $\begin{array}{c}\log (1+ \\
\text { Inventory })\end{array}$ & $\begin{array}{c}\log (1+ \\
\text { Cash\&ST Inv. })\end{array}$ & $\begin{array}{c}\log (1+ \\
\text { LT Debt Red.) }\end{array}$ \\
\hline & (1) & $(2)$ & (3) & (4) & (5) & (6) \\
\hline Log(Equity Inflows) $*$ Large Firm & $\begin{array}{l}0.0656 \text { *** } \\
(0.004)\end{array}$ & $\begin{array}{l}0.0256 * * * \\
(0.004)\end{array}$ & $\begin{array}{l}0.0317 \text { *** } \\
(0.009)\end{array}$ & $\begin{array}{l}0.0399 \text { *** } \\
(0.006)\end{array}$ & $\begin{array}{l}0.0652 \text { *** } \\
(0.006)\end{array}$ & $\begin{array}{l}0.0241 * * \\
(0.012)\end{array}$ \\
\hline $\begin{array}{l}\text { Firm FE } \\
\text { Country-Year FE } \\
\text { Number of Observations }\end{array}$ & $\begin{array}{c}\text { Yes } \\
\text { Yes } \\
81,018 \\
\end{array}$ & $\begin{array}{l}\text { Yes } \\
\text { Yes } \\
59,913 \\
\end{array}$ & $\begin{array}{c}\text { Yes } \\
\text { Yes } \\
25,721 \\
\end{array}$ & $\begin{array}{c}\text { Yes } \\
\text { Yes } \\
78,428 \\
\end{array}$ & $\begin{array}{l}\text { Yes } \\
\text { Yes } \\
79,430 \\
\end{array}$ & $\begin{array}{c}\text { Yes } \\
\text { Yes } \\
59,692 \\
\end{array}$ \\
\hline \multicolumn{7}{|c|}{ Panel B. Lagged Inflows } \\
\hline & $\begin{array}{c}\log (1+ \\
\text { CAPEX })\end{array}$ & $\begin{array}{c}\log (1+ \\
\text { Acquisitions })\end{array}$ & $\begin{array}{c}\log (1+ \\
\mathrm{R} \& \mathrm{D})\end{array}$ & $\begin{array}{c}\log (1+ \\
\text { Inventory) }\end{array}$ & $\begin{array}{c}\log (1+ \\
\text { Cash\&ST Inv.) }\end{array}$ & $\begin{array}{c}\log (1+ \\
\text { LT Debt Red.) }\end{array}$ \\
\hline & $(1)$ & (2) & (3) & (4) & (5) & $(6)$ \\
\hline Log(Lagged Equity Inflows) $*$ Large Firm & $\begin{array}{l}0.0642 \text { *** } \\
(0.003)\end{array}$ & $\begin{array}{l}0.0242 * * * \\
(0.004)\end{array}$ & $\begin{array}{l}0.0315 * * * \\
(0.009)\end{array}$ & $\begin{array}{l}0.0383 \text { *** } \\
(0.006)\end{array}$ & $\begin{array}{l}0.0627^{* * * *} \\
(0.005)\end{array}$ & $\begin{array}{l}0.0219 \text { ** } \\
(0.011)\end{array}$ \\
\hline Firm FE & Yes & Yes & Yes & Yes & Yes & Yes \\
\hline Country-Year FE & Yes & Yes & Yes & Yes & Yes & Yes \\
\hline Number of Observations & 79,259 & 59,198 & 25,381 & 76,779 & 77,753 & 58,971 \\
\hline
\end{tabular}




\section{Table 10}

\section{Equity Issuances and Subsequent Use of Funds by Large Firms}

This table reports firm-level panel OLS regressions for the use-of-funds analysis for equity issuers classified as large firms (top decile of the prior period's equity market value distribution within a country and year) for 25 emerging market countries during the 1991-2016 period. The analysis follows the specification of Kim and Weisbach (2008). The dependent variable for balance-sheet variables (inventory or cash and short-term investment) is $\mathrm{Y}=\log [((\mathrm{Vi}-\mathrm{V} 0) / \mathrm{Assets})+1]$. The dependent variable for cash-flow statement and income statement variables (capital expenditures, acquisitions, research and development expenditures, or reduction in long-term debt $)$ is $\mathrm{Y}=\log \left[\left(\sum_{\mathrm{i}} \mathrm{Vi} /\right.\right.$ Assets $\left.)+1\right]$. Independent variables are equity issuance value and other sources of funds, both normalized by total assets, in addition to the log of total assets. Total assets are measured at the value of the year just before the issuance. Dollar changes capture the change in the dependent variable resulting from a one-million-dollar increase in a firm's equity issuance. All variables are winsorized at the $1 \%$ level. All regressions include country and year fixed effects. Standard errors are clustered at the industry (two-digit SIC) level. *, **, and *** indicate statistical significance at the $10 \%, 5 \%$, and $1 \%$ levels, respectively.

\begin{tabular}{|c|c|c|c|c|c|c|}
\hline & \multirow{2}{*}{$\begin{array}{c}\text { Years After } \\
\text { Issuance } \\
\text { (Issuance at } \mathrm{t}=1 \text { ) }\end{array}$} & \multirow[t]{2}{*}{$\mathrm{N}$} & \multicolumn{2}{|c|}{$\log \left(\frac{\text { Issuance }}{\text { Assets }_{0}}+1\right)$} & \multirow[t]{2}{*}{ \$ Change } & \multirow[t]{2}{*}{$\mathrm{R}^{2}$} \\
\hline & & & $\beta 1$ & t-stat & & \\
\hline \multirow[t]{4}{*}{$\sum \mathrm{CAPEX}$} & 1 & 1,579 & $0.1797 * * *$ & 3.538 & 0.1812 & 0.258 \\
\hline & 2 & 1,529 & $0.3848 * * *$ & 5.736 & 0.4065 & 0.334 \\
\hline & 3 & 1,361 & $0.4883 * * *$ & 5.379 & 0.5409 & 0.361 \\
\hline & 4 & 1,179 & $0.5950 * * *$ & 5.334 & 0.6921 & 0.392 \\
\hline \multirow[t]{4}{*}{$\sum$ Acquisitions } & 1 & 1,464 & $0.2058 * * *$ & 2.733 & 0.2005 & 0.174 \\
\hline & 2 & 1,350 & $0.1743 * * *$ & 2.709 & 0.1702 & 0.182 \\
\hline & 3 & 1,126 & $0.2237 * * *$ & 2.785 & 0.2172 & 0.214 \\
\hline & 4 & 937 & 0.1570 & 1.636 & 0.1529 & 0.188 \\
\hline \multirow[t]{4}{*}{$\sum \mathrm{R} \& \mathrm{D}$} & 1 & 464 & 0.0090 & 1.414 & 0.0083 & 0.239 \\
\hline & 2 & 407 & 0.0132 & 0.810 & 0.0123 & 0.220 \\
\hline & 3 & 343 & 0.0866 & 1.508 & 0.0815 & 0.308 \\
\hline & 4 & 266 & 0.1528 & 1.471 & 0.1439 & 0.326 \\
\hline \multirow[t]{4}{*}{$\Delta$ Inventory } & 1 & 1,183 & $0.0673 *$ & 1.762 & 0.0636 & 0.129 \\
\hline & 2 & 1,160 & $0.0979 * *$ & 2.464 & 0.0930 & 0.150 \\
\hline & 3 & 1,040 & $0.1282 * * *$ & 3.626 & 0.1218 & 0.172 \\
\hline & 4 & 899 & 0.1256 *** & 2.796 & 0.1201 & 0.184 \\
\hline \multirow[t]{4}{*}{$\Delta$ Cash \& ST Inv. } & 1 & 1,207 & $0.5089 * * *$ & 7.470 & 0.4872 & 0.273 \\
\hline & 2 & 1,188 & $0.2767 * * *$ & 3.735 & 0.2642 & 0.172 \\
\hline & 3 & 1,068 & $0.2572 * *$ & 2.521 & 0.2429 & 0.189 \\
\hline & 4 & 927 & 0.1604 & 1.572 & 0.1554 & 0.216 \\
\hline \multirow{4}{*}{$\begin{array}{l}\sum \text { LT Debt } \\
\text { Reduction }\end{array}$} & 1 & 1,495 & -0.0204 & -0.201 & -0.0208 & 0.319 \\
\hline & 2 & 1,418 & -0.1184 & -1.281 & -0.1234 & 0.358 \\
\hline & 3 & 1,237 & -0.0873 & -0.824 & -0.0952 & 0.392 \\
\hline & 4 & 1,052 & -0.0570 & -0.505 & -0.0656 & 0.408 \\
\hline
\end{tabular}


Appendix Figure 1

Emerging Market Equity Issuance Including IPO and Equity Capital Inflows

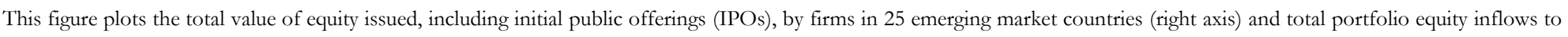
those emerging markets (left axis) during the 1991-2016 period. All values are reported in billions of 2011 U.S. dollars (USD).

250

350

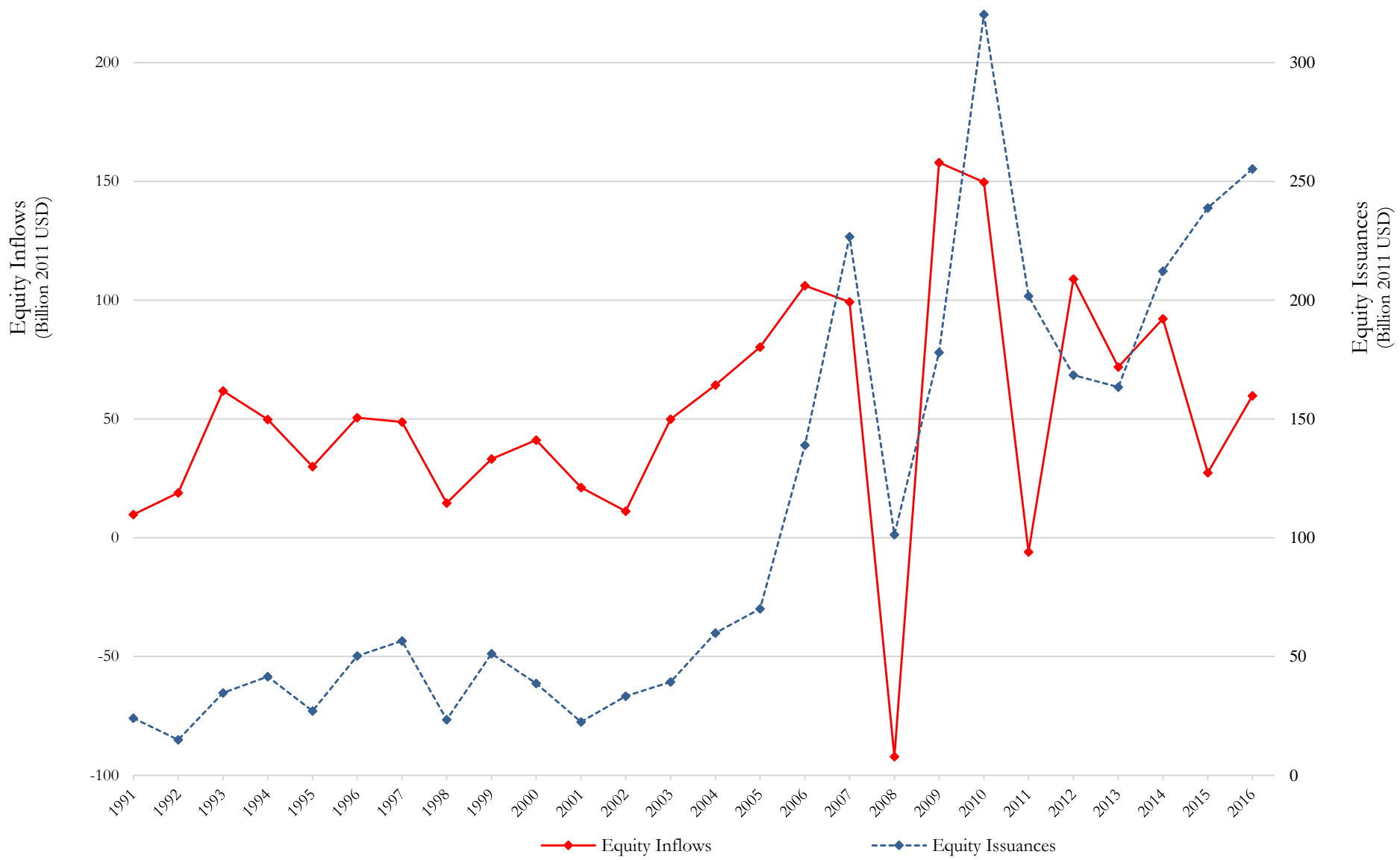




\section{Appendix Table 1 \\ Equity Inflows and Equity Issuance Activity: Aggregate Evidence Robustness Checks}

This table reports country-level panel OLS regressions of the log of one plus aggregate equity issuance on the log of portfolio equity inflows, for 25 emerging market countries during the 1991-2016 period. Issuances in column (1) include only seasoned equity offerings (SEOs). Issuances in column (2) include both SEOs and IPOs. Issuances in column (3) include only SEOs and excludes issuances by finance, insurance, and real estate firms. All variables are winsorized at the $1 \%$ level. All regressions include country and year fixed effects. Standard errors are double clustered at the country and year levels. ${ }^{* *}$, and $* * *$ indicate statistical significance at the $10 \%, 5 \%$, and $1 \%$ levels, respectively.

$\log (1+$ Equity Issuance $)$

\begin{tabular}{|c|c|c|c|}
\hline & \multicolumn{3}{|c|}{$\log (1+$ Equity Issuance $)$} \\
\hline & $\begin{array}{c}\text { All Sectors, } \\
\text { Excluding IPOs }\end{array}$ & $\begin{array}{c}\text { All Sectors, } \\
\text { Including IPOs }\end{array}$ & $\begin{array}{c}\text { Non-Financial Sectors, } \\
\text { Excluding IPOs }\end{array}$ \\
\hline & (1) & $(2)$ & (3) \\
\hline Log(Equity Inflows) & $\begin{array}{l}0.5240 \text { *** } \\
(0.093)\end{array}$ & $\begin{array}{l}0.5305 \text { *** } \\
(0.100)\end{array}$ & $\begin{array}{l}0.5130 * * * \\
(0.099)\end{array}$ \\
\hline Country FE & Yes & Yes & Yes \\
\hline Year FE & Yes & Yes & Yes \\
\hline Number of Observations & 428 & 428 & 428 \\
\hline
\end{tabular}




\section{Appendix Table 2}

\section{Market Value of Foreign Equity Issuers and Firms Included in the MSCI Index Percentiles}

This table reports the percentiles associated with foreign equity issuers and firms included in the MSCI index in the total firm size distribution for each country. The country size is computed by taking the mean of the firm's market value of equity within the country. The mean percentile across countries is computed by taking the average of the countries' percentile. Columns (1) and (2) report the percentiles for foreign equity issuers during the 1991-2016 period and for the firms included in the MSCI Index during the 2006-2016 period, respectively.

\begin{tabular}{|c|c|c|}
\hline \multirow[t]{2}{*}{ Country } & \multirow{2}{*}{$\begin{array}{l}\text { Percentile of Foreign Equity Issuers } \\
\qquad(\%) \\
(1)\end{array}$} & \multirow{2}{*}{$\begin{array}{l}\text { Percentile of Firms in the MSCI } \\
\text { Index }(\%) \\
(2)\end{array}$} \\
\hline & & \\
\hline Argentina & 95 & 84 \\
\hline Brazil & 95 & 91 \\
\hline Chile & 90 & 98 \\
\hline China & 97 & 98 \\
\hline Colombia & 99 & 91 \\
\hline Czech Republic & 46 & 76 \\
\hline Egypt, Arab Rep. & 98 & 97 \\
\hline Hungary & 52 & 95 \\
\hline India & 91 & 99 \\
\hline Indonesia & 97 & 98 \\
\hline Israel & 82 & 97 \\
\hline Jordan & 91 & 98 \\
\hline Korea, Rep. & 98 & 98 \\
\hline Malaysia & 92 & 99 \\
\hline Mexico & 93 & 93 \\
\hline Morocco & $\mathrm{N} / \mathrm{A}$ & 96 \\
\hline Pakistan & 86 & 98 \\
\hline Peru & 64 & $\mathrm{~N} / \mathrm{A}$ \\
\hline Philippines & 95 & 97 \\
\hline Poland & 95 & 98 \\
\hline Russian Federation & 89 & 90 \\
\hline South Africa & 86 & 93 \\
\hline Thailand & 98 & 99 \\
\hline Turkey & 94 & 96 \\
\hline Venezuela, R.B. & 96 & 88 \\
\hline Average & 88 & 94 \\
\hline
\end{tabular}




\section{Appendix Table 3}

\section{Equity Inflows and Firms' Equity Issuance Activity, Adding First-Stage Controls Instrument: Other Countries' Orthogonalized Equity Issuance Volume}

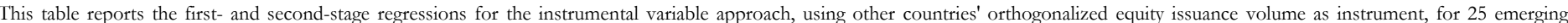

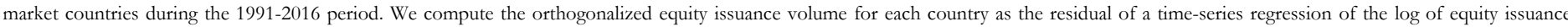

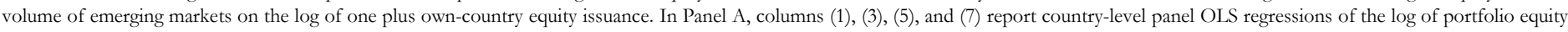

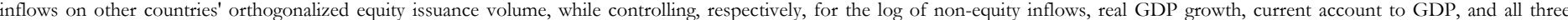

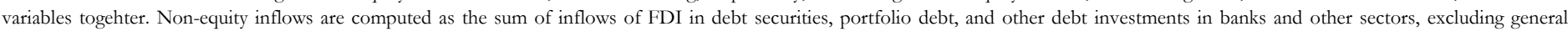

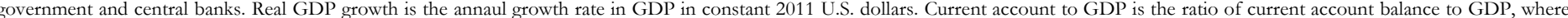

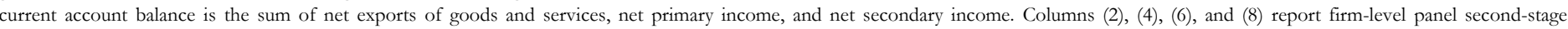

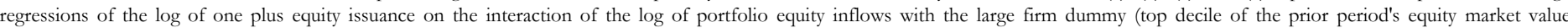

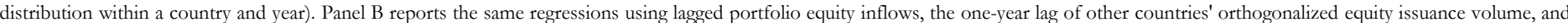

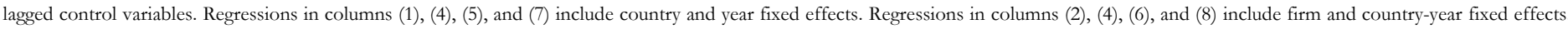

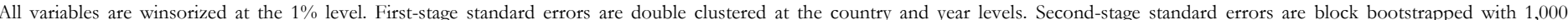
repetitions, double clustering at the country and year levels. ${ }^{*}, *$, and $* * *$ indicate statistical significance at the $10 \%, 5 \%$, and $1 \%$ levels, respectively.

\begin{tabular}{|c|c|c|c|c|c|c|c|c|}
\hline \multicolumn{9}{|c|}{ Panel A. Contemporaneous Inflows } \\
\hline & First Stage & Second Stage & First Stage & Second Stage & First Stage & Second Stage & First Stage & Second Stage \\
\hline & $\begin{array}{l}\log (\text { Equity } \\
\text { Inflows) }\end{array}$ & $\begin{array}{c}\log (1+ \\
\text { Equity } \\
\text { Issuance) }\end{array}$ & $\begin{array}{l}\log (\text { Equity } \\
\text { Inflows) }\end{array}$ & $\begin{array}{c}\log (1+ \\
\text { Equity } \\
\text { Issuance) }\end{array}$ & $\begin{array}{l}\log (\text { Equity } \\
\text { Inflows) }\end{array}$ & $\begin{array}{c}\log (1+ \\
\text { Equity } \\
\text { Issuance) }\end{array}$ & $\begin{array}{c}\log (\text { Equity } \\
\text { Inflows) }\end{array}$ & $\begin{array}{c}\log (1+ \\
\text { Equity } \\
\text { Issuance) }\end{array}$ \\
\hline & $(1)$ & $(2)$ & (3) & $(4)$ & $(5)$ & $(6)$ & $(7)$ & $(8)$ \\
\hline Other Countries' Orthogonalized Equity Issuane Volume & $\begin{array}{l}-0.7626 \text { *** } \\
(0.213)\end{array}$ & & $\begin{array}{l}-0.7408 \text { *** } \\
(0.189)\end{array}$ & & $\begin{array}{l}-0.6865 \text { *** } \\
(0.196)\end{array}$ & & $\begin{array}{c}-0.6496 \text { *** } \\
(0.230)\end{array}$ & \\
\hline Log(Equity Inflows) & & $\begin{array}{l}0.0214 \text { *** } \\
(0.003)\end{array}$ & & $\begin{array}{l}0.0215 \text { *** } \\
(0.003)\end{array}$ & & $\begin{array}{l}0.0213 \text { *** } \\
(0.002)\end{array}$ & & $\begin{array}{l}0.0212 \text { *** } \\
(0.003)\end{array}$ \\
\hline Log(Non-Equity Inflows) & $\begin{array}{l}0.1760 \text { ** } \\
(0.083)\end{array}$ & & & & & & $\begin{array}{l}0.1460 * \\
(0.073)\end{array}$ & \\
\hline Real GDP Growth & & & $\begin{array}{l}0.1594 \\
(0.495)\end{array}$ & & & & $\begin{array}{l}0.8873 \\
(0.612)\end{array}$ & \\
\hline Current Account to GDP & & & & & $\begin{array}{l}-0.0538 \text { *** } \\
(0.017)\end{array}$ & & $\begin{array}{l}-0.0556 \text { *** } \\
(0.018)\end{array}$ & \\
\hline $\begin{array}{l}\text { Firm FE } \\
\text { Country FE } \\
\text { Year FE } \\
\text { Country-Year } \\
\text { Number of Observations } \\
\text { Kleibergen-Paap Wald F-Stat }\end{array}$ & $\begin{array}{c}\text { No } \\
\text { Yes } \\
\text { Yes } \\
\text { No } \\
349 \\
13.91 \\
\end{array}$ & $\begin{array}{c}\text { Yes } \\
\text { No } \\
\text { No } \\
\text { Yes } \\
74,575 \\
. . \\
\end{array}$ & $\begin{array}{l}\text { No } \\
\text { Yes } \\
\text { Yes } \\
\text { No } \\
427 \\
8.19 \\
\end{array}$ & $\begin{array}{c}\text { Yes } \\
\text { No } \\
\text { No } \\
\text { Yes } \\
88,299 \\
. . \\
\end{array}$ & $\begin{array}{c}\text { No } \\
\text { Yes } \\
\text { Yes } \\
\text { No } \\
427 \\
16.49 \\
\end{array}$ & $\begin{array}{c}\text { Yes } \\
\text { No } \\
\text { No } \\
\text { Yes } \\
88,299 \\
. . \\
\end{array}$ & $\begin{array}{c}\text { No } \\
\text { Yes } \\
\text { Yes } \\
\text { No } \\
348 \\
7.94 \\
\end{array}$ & $\begin{array}{c}\text { Yes } \\
\text { No } \\
\text { No } \\
\text { Yes } \\
74,560 \\
. . \\
\end{array}$ \\
\hline \multicolumn{9}{|c|}{ Panel B. Lagged Inflows } \\
\hline & $\begin{array}{l}\text { First Stage } \\
\text { Log(Lagged } \\
\text { Equity } \\
\text { Inflows) }\end{array}$ & $\begin{array}{l}\text { Second Stage } \\
\log (1+ \\
\text { Equity } \\
\text { Issuance })\end{array}$ & $\begin{array}{c}\text { First Stage } \\
\text { Log(Lagged } \\
\text { Equity } \\
\text { Inflows) }\end{array}$ & $\begin{array}{l}\text { Second Stage } \\
\log (1+ \\
\text { Equity } \\
\text { Issuance })\end{array}$ & $\begin{array}{l}\text { First Stage } \\
\text { Log(Lagged } \\
\text { Equity } \\
\text { Inflows) }\end{array}$ & $\begin{array}{l}\text { Second Stage } \\
\log (1+ \\
\text { Equity } \\
\text { Issuance })\end{array}$ & $\begin{array}{c}\text { First Stage } \\
\text { Log(Lagged } \\
\text { Equity } \\
\text { Inflows) }\end{array}$ & $\begin{array}{c}\text { Second Stage } \\
\log (1+ \\
\text { Equity } \\
\text { Issuance })\end{array}$ \\
\hline & $(1)$ & $(2)$ & $(3)$ & $(4)$ & $(5)$ & $(6)$ & $(7)$ & $(8)$ \\
\hline Lagged Other Countries' Orthogonalized Equity Issuance Volume & $\begin{array}{l}-0.8111 * * * \\
(0.221)\end{array}$ & & $\begin{array}{l}-0.7815 \text { *** } \\
(0.193)\end{array}$ & & $\begin{array}{l}-0.7249 \text { *** } \\
(0.201)\end{array}$ & & $\begin{array}{l}-0.6940 \text { *** } \\
(0.241)\end{array}$ & \\
\hline Log(Lagged Equity Inflows) & & $\begin{array}{l}0.0212 \text { *** } \\
(0.004)\end{array}$ & & $\begin{array}{l}0.0178 \text { *** } \\
(0.004)\end{array}$ & & $\begin{array}{l}0.0176 \text { *** } \\
(0.004)\end{array}$ & & $\begin{array}{l}0.0208 \text { *** } \\
(0.003)\end{array}$ \\
\hline Log(Lagged Non-Equity Inflows) & $\begin{array}{l}0.1729 * \\
(0.089)\end{array}$ & & & & & & $\begin{array}{l}0.1427 * \\
(0.078)\end{array}$ & \\
\hline Lagged Real GDP Growth & & & $\begin{array}{l}0.1767 \\
(0.512)\end{array}$ & & & & $\begin{array}{l}0.9133 \\
(0.651)\end{array}$ & \\
\hline Lagged Current Account to GDP & & & & & $\begin{array}{l}-0.0539 \text { *** } \\
(0.017)\end{array}$ & & $\begin{array}{l}-0.0559 \text { *** } \\
(0.018)\end{array}$ & \\
\hline Firm FE & No & Yes & No & Yes & No & Yes & No & Yes \\
\hline Country FE & Yes & No & Yes & No & Yes & No & Yes & No \\
\hline Year FE & Yes & No & Yes & No & Yes & No & Yes & No \\
\hline Country-Year & No & Yes & No & Yes & No & Yes & No & Yes \\
\hline Number of Observations & 337 & 75,723 & 412 & 88,098 & 412 & 88,098 & 336 & 75,709 \\
\hline Kleibergen-Paap Wald F-Stat & 13.84 &.. & 8.69 &.. & 17.55 & .. & 7.62 &.. \\
\hline
\end{tabular}




\section{Appendix Table 4 \\ Equity Inflows, Bond Inflows and Firms' Equity and Bond Issuance Activity Instrument: Other Countries' Orthogonalized Equity Issuance Volume}

This table reports the first- and second-stage regressions for the instrumental variable approach, using other countries' orthogonalized equity issuance volume as instrument, for 25 emerging market countries during the 1991-2016 period. We compute the orthogonalized equity issuance volume for each country as the residual of a time-series regression of the log of equity issuance volume of emerging markets on the log of one plus own-country equity issuance. In Panel A, columns (1) and (3) report country-level panel OLS regressions of the log of portfolio debt inflows on other countries' orthogonalized equity issuance volume, while column (5) reports country-level panel OLS regressions of the log of portfolio equity inflows on other countries' orthogonalized equity issuance volume. Column (2) reports firm-level panel second-stage regressions of the log of one plus bond issuance on the interaction of the log of portfolio debt inflows with the large firm dummy (top decile of the prior period's equity market value distribution within a country and year). Column (4) reports firm-level panel second-stage regressions of the log of one plus equity issuance on the interaction of the log of portfolio debt inflows with the large firm dummy. Column (6) reports firm-level panel second-stage regressions of the log of one plus bond issuance on the interaction of the log of portfolio equity inflows with the large firm dummy. Panel B reports the same regressions using lagged portfolio equity and debt inflows and the one-year lag of other countries' orthogonalized equity issuance volume. Regressions in columns (1), (3), and (5) include country and year fixed effects. Regressions in columns (2), (4), and (6) include firm and country-year fixed effects. All variables are winsorized at the $1 \%$ level. First-stage standard errors are double clustered at the country and year levels. Second-stage standard errors are block bootstrapped with 1,000 repetitions, double clustering at the country and year levels. *, **, and *** indicate statistical significance at the $10 \%, 5 \%$, and $1 \%$ levels, respectively.

\begin{tabular}{|c|c|c|c|c|c|c|}
\hline \multicolumn{7}{|c|}{ Panel A. Contemporaneous Inflows } \\
\hline & First Stage & Second Stage & First Stage & Second Stage & First Stage & Second Stage \\
\hline & $\begin{array}{l}\log (\text { Bond } \\
\text { Inflows) }\end{array}$ & $\begin{array}{c}\log (1+ \\
\text { Bond } \\
\text { Issuance })\end{array}$ & $\begin{array}{l}\log (\text { Bond } \\
\text { Inflows) }\end{array}$ & $\begin{array}{c}\log (1+ \\
\text { Equity } \\
\text { Issuance) }\end{array}$ & $\begin{array}{l}\log (\text { Equity } \\
\text { Inflows) }\end{array}$ & $\begin{array}{c}\log (1+ \\
\text { Bond } \\
\text { Issuance })\end{array}$ \\
\hline & $(1)$ & $(2)$ & (3) & (4) & (5) & $(6)$ \\
\hline Other Countries' Orthogonalized Equity Issuance Volume & $\begin{array}{c}-0.6856 * \\
(0.387)\end{array}$ & & $\begin{array}{c}-0.7424 \text { *** } \\
(0.218)\end{array}$ & & $\begin{array}{c}-0.3691 \text { *** } \\
(0.094)\end{array}$ & \\
\hline $\log ($ Bond Inflows $) *$ Large Firm & & $\begin{array}{l}0.0429 \text { *** } \\
(0.014)\end{array}$ & & $\begin{array}{l}0.0010 \\
(0.008)\end{array}$ & & \\
\hline $\log ($ Equity Inflows $) *$ Large Firm & & & & & & $\begin{array}{l}0.0491 * * * \\
(0.010)\end{array}$ \\
\hline Firm FE & No & Yes & No & Yes & No & Yes \\
\hline Country FE & Yes & No & Yes & No & Yes & No \\
\hline Year FE & Yes & No & Yes & No & Yes & No \\
\hline Country-Year & No & Yes & No & Yes & No & Yes \\
\hline Number of Observations & 298 & 19,378 & 298 & 45,810 & 428 & 35,890 \\
\hline Kleibergen-Paap Wald F-Stat & 3.14 & .. & 11.56 & .. & 15.33 & .. \\
\hline \multicolumn{7}{|c|}{ Panel B. Lagged Inflows } \\
\hline & First Stage & Second Stage & First Stage & Second Stage & First Stage & Second Stage \\
\hline & $\begin{array}{c}\text { Log(Lagged } \\
\text { Bond } \\
\text { Inflows) }\end{array}$ & $\begin{array}{c}\log (1+ \\
\text { Bond } \\
\text { Issuance) }\end{array}$ & $\begin{array}{c}\text { Log(Lagged } \\
\text { Bond } \\
\text { Inflows) }\end{array}$ & $\begin{array}{c}\log (1+ \\
\text { Equity } \\
\text { Issuance })\end{array}$ & $\begin{array}{c}\text { Log(Lagged } \\
\text { Equity } \\
\text { Inflows) }\end{array}$ & $\begin{array}{c}\log (1+ \\
\text { Bond } \\
\text { Issuance) }\end{array}$ \\
\hline & $(1)$ & $(2)$ & (3) & (4) & (5) & (6) \\
\hline Lagged Other Countries' Orthogonalized Equity Issuance Volume & $\begin{array}{c}-0.7290 * \\
(0.402)\end{array}$ & & $\begin{array}{l}-0.7663 \text { *** } \\
(0.216)\end{array}$ & & $\begin{array}{l}-0.3940 * * * \\
(0.095)\end{array}$ & \\
\hline $\log ($ Lagged Bond Inflows $) *$ Large Firm & & $\begin{array}{l}0.0479 * * * \\
(0.013)\end{array}$ & & $\begin{array}{r}-0.0015 \\
(0.008)\end{array}$ & & \\
\hline Log(Lagged Equity Inflows $) *$ Large Firm & & & & & & $\begin{array}{l}0.0514 \text { *** } \\
(0.011)\end{array}$ \\
\hline Firm FE & No & Yes & No & Yes & No & Yes \\
\hline Country FE & Yes & No & Yes & No & Yes & No \\
\hline Year FE & Yes & No & Yes & No & Yes & No \\
\hline Country-Year & No & Yes & No & Yes & No & Yes \\
\hline Number of Observations & 291 & 19,754 & 291 & 47,063 & 413 & 35,836 \\
\hline Kleibergen-Paap Wald F-Stat & 3.28 & .. & 12.56 & .. & 17.21 &.. \\
\hline
\end{tabular}




\section{Appendix Table 5 \\ Real Economic Effects of Equity Inflows \\ Instrument: Other Countries' Orthogonalized Equity Value Excluding Financial Firms}

This table reports the second stage of firm-level panel instrumental variable regressions of the log of one plus firm real and financial outcomes on the interaction of the $\log$ of contemporaneous (Panel A) and lagged (Panel B) portfolio equity inflows with the large firm dummy (top decile of the prior period's equity market value distribution within a country and year) for 25 emerging market countries during the 1991-2016 period, excluding from the sample all financial, insurance, and real estate firms. We use the contemporaneous and lagged values of other countries' orthogonalized equity value as instruments for the contemporaneous and lagged portfolio equity inflows, respectively. We compute the orthogonalized equity value for each country as the residual of a time-series regression of the log of market vale of emerging markets on the log of own-country market value. The dependent variables are capital expenditures, acquisitions, research and development expenditures, inventory accumulation, cash and short-term investments accumulation, and reduction of long-term debt. All variables are winsorized at the $1 \%$ level. Standard errors are block bootstrapped with 1,000 repetitions, double clustering at the country and year levels. All regressions include firm and country-year fixed effects. $*, * *$, and $* * *$ indicate statistical significance at the $10 \%, 5 \%$, and $1 \%$ levels, respectively.

\begin{tabular}{|c|c|c|c|c|c|c|}
\hline \multicolumn{7}{|c|}{ Panel A. Contemporaneous Inflows } \\
\hline & $\begin{array}{c}\log (1+ \\
\text { CAPEX) }\end{array}$ & $\begin{array}{c}\log (1+ \\
\text { Acquisitions })\end{array}$ & $\begin{array}{c}\log (1+ \\
\mathrm{R} \& \mathrm{D})\end{array}$ & $\begin{array}{c}\log (1+ \\
\text { Inventory })\end{array}$ & $\begin{array}{c}\log (1+ \\
\text { Cash\&ST Inv. })\end{array}$ & $\begin{array}{c}\log (1+ \\
\text { LT Debt Red.) }\end{array}$ \\
\hline & $(1)$ & $(2)$ & (3) & (4) & (5) & $(6)$ \\
\hline Log(Equity Inflows) $*$ Large Firm & $\begin{array}{l}0.0678 \text { *** } \\
(0.005)\end{array}$ & $\begin{array}{l}0.0260 \text { *** } \\
(0.006)\end{array}$ & $\begin{array}{l}0.0312 \text { *** } \\
(0.009)\end{array}$ & $\begin{array}{l}0.0426 \text { *** } \\
(0.005)\end{array}$ & $\begin{array}{l}0.0602 \text { *** } \\
(0.006)\end{array}$ & $\begin{array}{l}0.0200 * * \\
(0.008)\end{array}$ \\
\hline $\begin{array}{l}\text { Firm FE } \\
\text { Country-Year FE } \\
\text { Number of Observations }\end{array}$ & $\begin{array}{c}\text { Yes } \\
\text { Yes } \\
71,768\end{array}$ & $\begin{array}{c}\text { Yes } \\
\text { Yes } \\
52,424\end{array}$ & $\begin{array}{c}\text { Yes } \\
\text { Yes } \\
25,365\end{array}$ & $\begin{array}{c}\text { Yes } \\
\text { Yes } \\
72,809\end{array}$ & $\begin{array}{c}\text { Yes } \\
\text { Yes } \\
73,096\end{array}$ & $\begin{array}{c}\text { Yes } \\
\text { Yes } \\
52,687\end{array}$ \\
\hline \multicolumn{7}{|c|}{ Panel B. Lagged Inflows } \\
\hline & $\begin{array}{c}\log (1+ \\
\text { CAPEX) }\end{array}$ & $\begin{array}{c}\log (1+ \\
\text { Acquisitions) }\end{array}$ & $\begin{array}{c}\log (1+ \\
\mathrm{R} \& \mathrm{D})\end{array}$ & $\begin{array}{c}\log (1+ \\
\text { Inventory })\end{array}$ & $\begin{array}{c}\log (1+ \\
\text { Cash\&ST Inv. })\end{array}$ & $\begin{array}{c}\log (1+ \\
\text { LT Debt Red.) }\end{array}$ \\
\hline & $(1)$ & $(2)$ & (3) & $(4)$ & $(5)$ & $(6)$ \\
\hline Log(Lagged Equity Inflows $) *$ Large Firm & $\begin{array}{l}0.0655 * * * \\
(0.004)\end{array}$ & $\begin{array}{l}0.0249 \text { *** } \\
(0.006)\end{array}$ & $\begin{array}{l}0.0297 * * * \\
(0.009)\end{array}$ & $\begin{array}{l}0.0403 \text { *** } \\
(0.005)\end{array}$ & $\begin{array}{l}0.0567 \text { *** } \\
(0.005)\end{array}$ & $\begin{array}{l}0.0164 * \\
(0.008)\end{array}$ \\
\hline Firm FE & Yes & Yes & Yes & Yes & Yes & Yes \\
\hline Country-Year FE & Yes & Yes & Yes & Yes & Yes & Yes \\
\hline Number of Observations & 70,163 & 51,818 & 25,020 & 71,248 & 71,519 & 52,056 \\
\hline
\end{tabular}




\section{Appendix Table 6 \\ Equity Issuances and Subsequent Use of Funds by Large Firms Excluding Financial Firms}

This table reports firm-level panel OLS regressions for the use-of-funds analysis for equity issuers classified as large firms (top decile of the prior period's equity market value distribution within a country and year) for 25 emerging market countries during the 1991-2016 period, excluding from the sample all finance, insurance, and real estate firms. The analysis follows the specification of Kim and Weisbach (2008). The dependent variable for balance-sheet variables (inventory or cash and short-term investment) is $\mathrm{Y}=\log [(\mathrm{Vi}-\mathrm{V} 0) /$ Assets $)+1]$. The dependent variable for cash-flow statement and income statement variables (capital expenditures, acquisitions, research and development expenditures, or reduction in long-term debt) is $\mathrm{Y}=\log \left[\left(\sum_{\mathrm{i}} \mathrm{Vi} /\right.\right.$ Assets $\left.)+1\right]$. Independent variables are equity issuance value and other sources of funds, both normalized by total assets, in addition to the log of total assets. Total assets are measured at the value of the year just before the issuance. Dollar changes capture the change in the dependent variable resulting from a one-million-dollar increase in a firm's equity issuance. All variables are winsorized at the $1 \%$ level. All regressions include country and year fixed effects. Standard errors are clustered at the industry (two-digit SIC) level. *, **, and *** indicate statistical significance at the $10 \%$, $5 \%$, and $1 \%$ levels, respectively.

\begin{tabular}{|c|c|c|c|c|c|c|}
\hline & \multirow{2}{*}{$\begin{array}{c}\text { Years After } \\
\text { Issuance } \\
\text { (Issuance at } \mathrm{t}=1 \text { ) }\end{array}$} & \multirow[t]{2}{*}{$\mathrm{N}$} & \multicolumn{2}{|c|}{$\log \left(\frac{\text { Issuance }}{\text { Assets }_{0}}+1\right)$} & \multirow[t]{2}{*}{ \$Change } & \multirow[t]{2}{*}{$\mathrm{R}^{2}$} \\
\hline & & & $\beta 1$ & t-stat & & \\
\hline \multirow[t]{4}{*}{$\sum$ CAPEX } & 1 & 1,209 & $0.1321 * * *$ & 2.757 & 0.1351 & 0.216 \\
\hline & 2 & 1,189 & $0.3181 * * *$ & 5.292 & 0.3461 & 0.310 \\
\hline & 3 & 1,066 & $0.3972 * * *$ & 5.241 & 0.4604 & 0.370 \\
\hline & 4 & 933 & $0.4586 * * *$ & 4.656 & 0.5590 & 0.421 \\
\hline \multirow[t]{4}{*}{$\sum$ Acquisitions } & 1 & 1,114 & $0.1797 * *$ & 2.579 & 0.1746 & 0.214 \\
\hline & 2 & 1,046 & $0.1341 * *$ & 2.465 & 0.1293 & 0.234 \\
\hline & 3 & 880 & $0.1763 * *$ & 2.596 & 0.1688 & 0.262 \\
\hline & 4 & 744 & 0.1105 & 1.212 & 0.1058 & 0.240 \\
\hline \multirow[t]{4}{*}{$\sum \mathrm{R} \& \mathrm{D}$} & 1 & 494 & 0.0095 & 1.386 & 0.0088 & 0.247 \\
\hline & 2 & 432 & 0.0225 & 1.156 & 0.0211 & 0.219 \\
\hline & 3 & 361 & $0.0788 *$ & 2.006 & 0.0749 & 0.355 \\
\hline & 4 & 281 & $0.1513 * *$ & 2.069 & 0.1434 & 0.376 \\
\hline \multirow[t]{4}{*}{$\Delta$ Inventory } & 1 & 1,207 & $0.0629 *$ & 1.746 & 0.0593 & 0.134 \\
\hline & 2 & 1,190 & $0.0903 * *$ & 2.324 & 0.0855 & 0.158 \\
\hline & 3 & 1,067 & $0.1226 * * *$ & 3.288 & 0.1155 & 0.184 \\
\hline & 4 & 932 & $0.1171 * *$ & 2.644 & 0.1101 & 0.195 \\
\hline \multirow[t]{4}{*}{$\Delta$ Cash \& ST Inv. } & 1 & 1,208 & $0.5025 * * *$ & 7.654 & 0.4796 & 0.269 \\
\hline & 2 & 1,190 & $0.2879 * * *$ & 3.919 & 0.2752 & 0.166 \\
\hline & 3 & 1,068 & $0.2753 * *$ & 2.652 & 0.2629 & 0.205 \\
\hline & 4 & 933 & $0.2286 * *$ & 2.351 & 0.2180 & 0.228 \\
\hline \multirow{4}{*}{$\begin{array}{l}\sum \text { LT Debt } \\
\text { Reduction }\end{array}$} & 1 & 1,183 & 0.0279 & 0.296 & 0.0282 & 0.415 \\
\hline & 2 & 1,159 & 0.0057 & 0.073 & 0.0060 & 0.484 \\
\hline & 3 & 1,028 & 0.0826 & 0.964 & 0.0938 & 0.515 \\
\hline & 4 & 887 & 0.0677 & 0.766 & 0.0814 & 0.527 \\
\hline
\end{tabular}




\section{Appendix Table 7 \\ Real Economic Effects of Equity Inflows Instrument: Other Countries' Orthogonalized Equity Issuance Volume}

This table reports the second stage of firm-level panel instrumental variable regressions of the log of one plus firm real and financial outcomes on the interaction of the log of contemporaneous (Panel A) and lagged (Panel B) portfolio equity inflows with the large firm dummy (top decile of the prior period's equity market value distribution within a country and year) for 25 emerging market countries during the 1991-2016 period. We use the contemporaneous and lagged values of other countries' orthogonalized equity issuance volume as instruments for the contemporaneous and lagged portfolio equity inflows, respectively. We compute the orthogonalized equity issuance for each country as the residual of a time-series regression of the log of equity issuance volume of emerging markets on the log of one plus own-country equity issuance. The dependent variables are capital expenditures, acquisitions, research and development expenditures, inventory accumulation, cash and short-term investments accumulation, and reduction of long-term debt. All variables are winsorized at the 1\% level. Standard errors are block bootstrapped with 1,000 repetitions, double clustering at the country and year levels. All Regressions include firm and country-year fixed effects. *, **, and *** indicate statistical significance at the $10 \%, 5 \%$, and $1 \%$ levels, respectively.

\begin{tabular}{|c|c|c|c|c|c|c|}
\hline \multicolumn{7}{|c|}{ Panel A. Contemporaneous Inflows } \\
\hline & $\begin{array}{c}\log (1+ \\
\text { CAPEX) }\end{array}$ & $\begin{array}{c}\log (1+ \\
\text { Acquisitions })\end{array}$ & $\begin{array}{c}\log (1+ \\
\operatorname{R} \& D)\end{array}$ & $\begin{array}{c}\log (1+ \\
\text { Inventory })\end{array}$ & $\begin{array}{c}\log (1+ \\
\text { Cash\&ST Inv.) }\end{array}$ & $\begin{array}{c}\log (1+ \\
\text { LT Debt Red. })\end{array}$ \\
\hline & $(1)$ & $(2)$ & (3) & (4) & $(5)$ & $(6)$ \\
\hline Log(Equity Inflows) $*$ Large Firm & $\begin{array}{l}0.0698 * * * \\
(0.004)\end{array}$ & $\begin{array}{l}0.0276 \text { *** } \\
(0.004)\end{array}$ & $\begin{array}{l}0.0362 * * * \\
(0.007)\end{array}$ & $\begin{array}{l}0.0448 \text { *** } \\
(0.005)\end{array}$ & $\begin{array}{l}0.0721 * * * \\
(0.006)\end{array}$ & $\begin{array}{l}0.0303 \text { *** } \\
(0.011)\end{array}$ \\
\hline $\begin{array}{l}\text { Firm FE } \\
\text { Country-Year FE } \\
\text { Number of Observations }\end{array}$ & $\begin{array}{c}\text { Yes } \\
\text { Yes } \\
84,121\end{array}$ & $\begin{array}{c}\text { Yes } \\
\text { Yes } \\
62,343\end{array}$ & $\begin{array}{c}\text { Yes } \\
\text { Yes } \\
26,479\end{array}$ & $\begin{array}{c}\text { Yes } \\
\text { Yes } \\
81,328 \\
\end{array}$ & $\begin{array}{c}\text { Yes } \\
\text { Yes } \\
82,364 \\
\end{array}$ & $\begin{array}{c}\text { Yes } \\
\text { Yes } \\
62,151 \\
\end{array}$ \\
\hline \multicolumn{7}{|c|}{ Panel B. Lagged Inflows } \\
\hline & $\begin{array}{c}\log (1+ \\
\text { CAPEX })\end{array}$ & $\begin{array}{c}\log (1+ \\
\text { Acquisitions })\end{array}$ & $\begin{array}{c}\log (1+ \\
\mathrm{R} \& \mathrm{D})\end{array}$ & $\begin{array}{c}\log (1+ \\
\text { Inventory) }\end{array}$ & $\begin{array}{c}\log (1+ \\
\text { Cash\&ST Inv. })\end{array}$ & $\begin{array}{c}\log (1+ \\
\text { LT Debt Red.) }\end{array}$ \\
\hline & (1) & $(2)$ & (3) & (4) & (5) & $(6)$ \\
\hline Log(Lagged Equity Inflows $) *$ Large Firm & $\begin{array}{l}0.0693 * * * \\
(0.004)\end{array}$ & $\begin{array}{l}0.0259 \text { *** } \\
(0.003)\end{array}$ & $\begin{array}{l}0.0361 * * * \\
(0.006)\end{array}$ & $\begin{array}{l}0.0447^{* * *} \\
(0.005)\end{array}$ & $\begin{array}{l}0.0721 * * * \\
(0.006)\end{array}$ & $\begin{array}{l}0.0276 \text { *** } \\
(0.010)\end{array}$ \\
\hline Firm FE & Yes & Yes & Yes & Yes & Yes & Yes \\
\hline Country-Year FE & Yes & Yes & Yes & Yes & Yes & Yes \\
\hline Number of Observations & 83,930 & 62,226 & 26,308 & 81,192 & 82,202 & 62,066 \\
\hline
\end{tabular}

